\title{
Chemical Variations on the p53 Reactivation Theme
}

\author{
Carlos J. A. Ribeiro, Cecília M. P. Rodrigues, Rui Moreira and Maria M. M. Santos * \\ Research Institute for Medicines (iMed.ULisboa), Faculty of Pharmacy, Universidade de Lisboa, \\ 1649-003 Lisboa, Portugal; cjacribeiro@ff.ulisboa.pt (C.J.A.R.); cmprodrigues@ff.ulisboa.pt (C.M.P.R.); \\ rmoreira@ff.ulisboa.pt (R.M.) \\ * Correspondence: mariasantos@ff.ulisboa.pt; Tel./Fax: +351-21-794-6470 \\ Academic Editors: Victor Freitas and Maria Emília de Sousa \\ Received: 13 April 2016; Accepted: 9 May 2016; Published: 13 May 2016
}

\begin{abstract}
Among the tumor suppressor genes, p53 is one of the most studied. It is widely regarded as the "guardian of the genome", playing a major role in carcinogenesis. In fact, direct inactivation of the TP53 gene occurs in more than 50\% of malignancies, and in tumors that retain wild-type p53 status, its function is usually inactivated by overexpression of negative regulators (e.g., MDM2 and MDMX). Hence, restoring p53 function in cancer cells represents a valuable anticancer approach. In this review, we will present an updated overview of the most relevant small molecules developed to restore p53 function in cancer cells through inhibition of the p53-MDMs interaction, or direct targeting of wild-type p53 or mutated p53. In addition, optimization approaches used for the development of small molecules that have entered clinical trials will be presented.
\end{abstract}

Keywords: small molecules; MDM2 inhibitors; MDMX inhibitors; p53 activators; p53-MDM2 interaction inhibitors; p53-MDMX interaction inhibitors; mutant p53; wild-type p53

\section{Introduction}

The tumor suppressor p53 was discovered over 35 years ago and plays a pivotal role in the regulation of cell cycle, apoptosis, DNA repair, senescence and angiogenesis [1]. Its central role as tumor suppressor is undeniable, as observed by the increased predisposition to cancer in individuals with Li-Fraumeni syndrome, who inherit a mutant TP53 gene, and in Trp-null mice [2]. Moreover, in virtually all cancers, loss of p53 function occurs, either directly due to the presence of a mutated form of TP53, or indirectly due to inactivation of the p53 signal transduction pathways. In tumors that retain wild-type p53 status (50\% of all cancers), its function is usually inactivated by overexpression of endogenous negative regulators, such as murine double minute-2 (MDM2) and MDM4 (also known as MDMX) [3].

Cellular levels of the p53 protein are tightly regulated. In normal cells, and under physiological conditions, steady-state levels of p53 are maintained very low by its negative regulators, mainly MDM2 and MDM4. However, under cellular stress, such as DNA damage, hypoxia or oncogene activation, a range of differential posttranslational modifications of p53 are triggered that lead to p53 stabilization and activation, by promoting its release from repression and by inhibiting degradation. For instance, upon acute DNA damage, p53 stabilization is mostly achieved by phosphorylation mediated by upstream kinases such as ATM/ATR and/or CHK1/CHK2. Activated p53 binds to DNA and promotes the transcription of several target genes, culminating in a proper cellular response that is dictated by the nature of the stress, cell type and environment milieu. Under low levels of stress, p53 induces a transient G1 cell cycle arrest, while cells attempt to repair their genome. However, if the damage is too severe, activation of the p53 pathway results in cell death by apoptosis or senescence. By contrast, loss of p53 tumor suppressor activity allows the proliferation of cells that are damaged under stress conditions, potentially leading to uncontrolled proliferation that can result in tumor development [4-6]. 
Canonical p53 responses that lead to cell cycle arrest, senescence and apoptosis are extensively studied specially when triggered upon acute DNA damage. Recently, however, more attention is given to understanding p53 signaling in a tumor context, since distinct stresses and different responses that can facilitate/trigger tumor suppression have been described. These interesting p53 responses include inhibition of oncogenic metabolic reprogramming, activation of autophagy, communication endorsement within the tumor microenvironment, inhibition of stem cell self-renewal and reprogramming of differentiated cells into stem cells, and limiting invasion and metastasis $[2,7]$.

\section{Reactivation of $\mathrm{p} 53$ as a Therapeutic Strategy}

It is well documented that the loss of p53 can induce tumor formation in mice, whereas its restoration often leads to a rapid regression of established in situ tumors [8], showcasing the anticancer therapeutic potential of p53 reactivation. Nevertheless, studies based on genetically engineered mice show an heterogeneous response to $\mathrm{p} 53$ restoration [9]. Furthermore, the key question for p53 reactivation strategy is whether or not this event will result in a selective effect on tumor cells as opposed to healthy tissues. It seems that a simple overexpression of p53 in cells is not sufficient to activate the p53 pathway. The restored p53 protein needs to be properly activated, and for that the transformed environment of tumor cells appears to be required [8,10]. For instance, studies using p53-MDM2 interaction inhibitors showed that in fact, in normal cells, the activation of p53 induces preferentially cell cycle arrest and not cell death, revealing therefore a more selective toxic effect on tumor cells [11,12]. The effect of p53 activation by this type of inhibitor in normal tissues has an immense interest from a therapeutic perspective due to the possibility of using it in monotherapy, as well as protector of normal cells in combination with more aggressive agents [11,12].

Throughout the last ten years, great advances were made in devising strategies to modulate p53, giving rise to several review papers on the subject [3,12-25]. Pharmacological p53 reactivation strategies for cancer therapy can be clustered in two major approaches based on p53 status. In tumors that retain wild-type p53 but have defects in p53 regulatory pathways, the main goal is to inhibit the function of negative regulators of p53 activation outcome. When p53 is mutated in tumors, the most common strategy consists in refolding the protein into a wild-type conformation to restore its function. In this review, emphasis will be given to small-molecules that restore p53 function in cancer cells. However, other strategies are also being pursued such as the use of peptides, stapled peptides and other oligomers to inhibit the p53-MDM2/X interactions [21], or the use of adenovirus-mediated p53 cancer gene therapy [26].

In this review, we will present an overview of the most relevant small molecules developed to activate p53. Table 1 presents all in vitro cell-free and cell-based methods used to determine the $\mathrm{IC}_{50}$ of the compounds discussed in this review, as well as the cell lines employed and their p53 status.

Table 1. Cell-free and cell-based in vitro assays.

\begin{tabular}{ll}
\hline & Cell-Free Binding Assays \\
\hline SPR & Surface plasmon resonance \\
HTRF & Homogeneous time resolved fluorescence \\
FP & Fluorescence polarization \\
NMR-AIDA & NMR-based antagonist induced dissociation assay \\
ThermoFluor & Thermal denaturation screening assay \\
TR-FRET & Time-resolved fluorescence energy transfer \\
ELISA & Enzyme-linked immunosorbent assay \\
\hline & \multicolumn{1}{c}{ Cell-Based Assays } \\
\hline BrdU & Bromo-2'-deoxyuridine \\
EdU & 5-Ethynyl-2'-deoxyuridine \\
LCVA & Luminescent cell viability assay \\
MTT & Tetrazolium salt \\
SRB & Sulforhodamine B \\
WST-8 & Water soluble tetrazolium salt \\
\hline
\end{tabular}


Table 1. Cont.

\begin{tabular}{ll}
\hline & \multicolumn{1}{c}{ Cell Lines } \\
\hline A549 & Human lung carcinoma-wild-type p53 \\
Fro & Human anaplastic thyroid carcinoma-null p53 \\
HCT116 $p 53^{(+/+)}$ & Human colorectal cancer-wild-type p53 \\
JAR & Human choriocarcinoma-wild-type p53 \\
Kat-4 & Human thyroid tumor-mutant p53 \\
LNCaP & Human prostatic adenocarcinoma-wild-type p53 \\
MCF-7 & Human breast adenocarcinoma-wild-type p53 \\
MDA-MB-231 & Human breast adenocarcinoma-mutant p53 \\
MHM & Human osteosarcoma-wild-type p53 \\
SJSA-1 & Human osteosarcoma-wild-type p53 \\
U-2OS & Human osteosarcoma-wild-type p53 \\
U937 & Human lung lymphoblast-wild-type p53 \\
\hline
\end{tabular}

\subsection{Targeting $p 53-M D M 2$ Interaction}

Increased levels of p53 repressor MDM2 are present in many cancers, mainly through MDM2 gene amplification or by activity loss of MDM2 inhibitor ARF. Therefore, targeting the p53-MDM2 interaction to reactivate p53 has emerged as a promising new cancer therapeutic strategy [11,27-46]. MDM2 and p53 regulate each other through an autoregulatory feedback loop [47]. Activation of p53 stimulates the transcription of MDM2, which in turn binds to the $\mathrm{N}$-terminal transactivation domain of p53, disabling its transcriptional function. MDM2 also promotes the nuclear export of p53 and p53 proteasome-mediated degradation through its E3 ubiquitin ligase activity by promoting mono and polyubiquitination, respectively, at several lysine residues. These events result in decreased levels of p53 that will therefore reduce MDM2 expression, allowing p53 protein to potentially be activated again $[45,48]$.

The crystal structure of the p53 binding domain of MDM2 (109-residue amino-terminal) with a short peptide of the p53 transactivaction domain (15 residues) has been solved and published, providing detailed information about the interaction between these two proteins [49]. The co-crystal revealed that MDM2 has a deep hydrophobic cleft on which the p53 peptide binds as an amphipathic alpha helix. In the bound conformation, the p53 amphipathic $\alpha$-residues 19-26 of the transactivation domain projects residues Phe19, Trp23 and Leu26 into the deep hydrophobic cleft of the MDM2 protein, representing the critical residues for binding between these two proteins to occur (Figure 1). In the crystal structure, Phe19 and Trp23 align in the deeper portion of the cleft. Phe19, through its backbone amine, forms one hydrogen bond with the backbone carbonyl Gln72 at the entrance of the cleft, while establishing hydrophobic interactions with Gly58 and Ile61 of MDM2. Trp23 occupies the deepest part of the binging pocket, forming a solvent protected hydrogen bond between the $\mathrm{NH}$ from its indole side chain and Leu54 of MDM2, and makes hydrophobic interactions with Gly58 and Ile61 of MDM2. Leu26 is the final residue of the alpha helix to be projected into the hydrophobic pocket. Furthermore, the interaction is strengthened by additional van der Waals contacts provided by p53 Leu22 $[40,49]$.

After publication of the crystal structure of p53 bound to MDM2, several efforts were made to design more potent peptide derivatives and small molecules to target this interaction. Currently, several different chemical classes have been described as p53-MDM2 interaction inhibitors, and some small molecules are already in clinical trials $[46,50]$. 


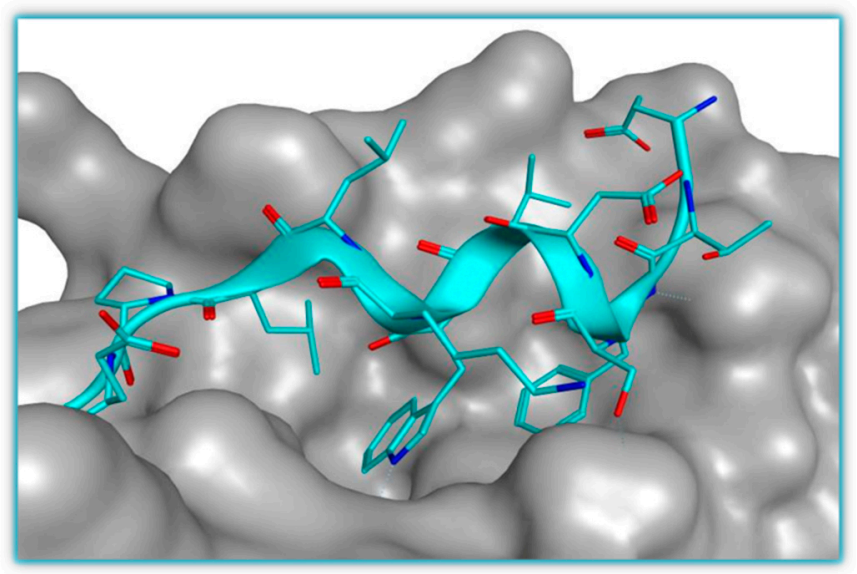

Figure 1. The p53-MDM2 interaction representation (PDB 1YCR). Phe19, Trp23 and Leu26 from a small amphipathic p53 derived $\alpha$-helix (blue) are projected into the MDM2 pocket (grey surface).

\section{p53-MDM2 Interaction Inhibitors}

During the last 15 years, several scaffolds have been described as p53-MDM2 interaction inhibitors and seven small molecules have advanced into clinical trials. The nutlin scaffold, consisting of a tetrasubstituted imidazoline unit, was first discovered by Hoffman-La Roche after a high-throughput screening (HTS) of a diverse library of synthetic compounds, using a surface plasmon resonance (SPR) assay, followed by structure-based optimization. This study provided three potent compounds for MDM2 and the first crystallographic structure of a small-molecule (nutlin-2: 1, Figure 2) in complex with MDM2 [51]. In the crystallographic structure the para-bromophenyl ring at position 4 occupies Leu26(p53) pocket while the para-bromophenyl substituent at position 5 inserts deeply into the Trp23(p53) pocket with the bromo atom enhancing the binding by filling a small cavity not normally occupied by the indole ring of p53 Trp23. The Phe19 ${ }_{(p 53)}$ pocket is occupied by the ethyl ether side chain of the third aromatic ring while its para-methoxy group mimics the p53 Leu22. The N1 chain functions mainly as a "solubility-tag" but also contributes to activity by possibly establishing polar interactions between the hydroxyl group and Gln72 side chain [51,52].

The most potent compound identified was the enantiopure nutlin-3a $\left(2, \mathrm{SPR} \mathrm{IC}_{50}=0.09 \mu \mathrm{M}\right.$, MTT IC I0 $_{1-1}=1 \mathrm{M}$ in wild-type p53 cancer cell lines), which has been used in monotherapy and in combination with other anti-cancer drugs and radiation, serving as proof-of-concept for nutlins and to establish p53-MDM2 interaction as a promising and valuable target [53-58]. However, the biological and pharmacokinetic (PK) properties of nutlin-3a were suboptimal for clinical development. The optimization of these properties was mainly focused on probing different $N 1$ side chains to enhance PK properties and MDM2 binding and on removing stability liabilities found in the previous compounds (oxidation of the main core to imidazole, and metabolization of the para-methoxyphenyl group to phenol). The PK properties were amended by adding methyl groups to positions 4 and 5 of the imidazoline ring, and by replacing the methoxy with a tert-butyl group [59]. One of the best compounds, RG7112 ( 3 , HTRF IC $50=18 \mathrm{nM}$, MTT IC $50=0.18-2.2 \mu \mathrm{M}$ in wild-type p53 cancer cell lines) entered clinical trials [60]. RG7112 shows good selectivity over mutated p53 cancer cells (MTT $\left.\mathrm{IC}_{50}=5.7-20.3 \mu \mathrm{M}\right)$, and it is able to activate the p53 signaling pathway in wild-type p53 cells, leading to cell cycle arrest and apoptosis. Furthermore a daily dose of $100 \mathrm{mg} / \mathrm{kg}$ is capable of promoting partly regression of SJSA-1 and MHM tumor xenograft mice models [46,61].

$\mathrm{Hu}$ et al. reported novel derivatives based on the imidazoline scaffold, mainly by varying the N1 side chain of nutlin-3. Compound 4 (FP IC $50=0.59 \mu \mathrm{M}$, MTT HCT116 $p 53^{+/+} \mathrm{IC}_{50}=3.73 \mu \mathrm{M}$, Figure 2) was one of the most potent compounds obtained, although not representing an improvement of potency when compared with nutlin-3a. Nevertheless, these studies helped establishing that changing $N 1$ side chain interferes mainly with PK properties but also with potency $[62,63]$. Several other analogs 
are disclosed in patents from Hoffman-La Roche, presenting the same imidazoline core and other structure variations such as imidazopyridinones [30,39,64,65]. Moreover, Miyazaki et al. also published a new series of dihydroimidazothiazole derivatives based on the nutlin-3a structure, such as DS-5272 $\left(5\right.$, HTRF IC ${ }_{50}=2.4 \mu \mathrm{M}$, LCVA SJSA-1 IC $\left.50=0.2 \mu \mathrm{M}\right)[66,67]$.

The screening of a library of 338.000 compounds using a miniaturized affinity-based assay, termed ThermoFluor, identified the 1,4-benzodiazepine-2,5-dione scaffold (BDP) [68]. Selected compounds from this first screen were further tested employing a fluorescence polarization (FP) assay to detect specific p53-MDM2 interaction inhibitors.
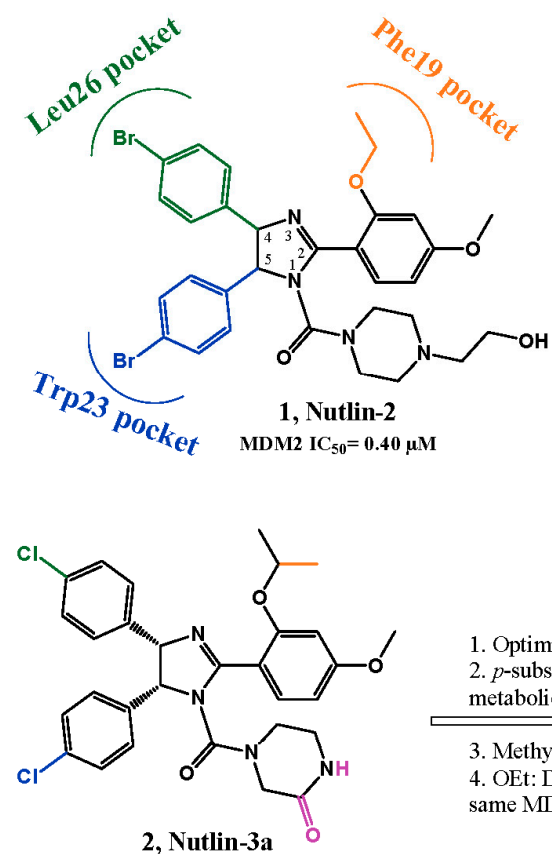

wt p53 cancer cell lines $\mathrm{IC}_{50}=1$ - $2 \mu \mathrm{M}$
1. Optimization $N 1$ chain: improve PK 2. $p$-substitution: increase metabolic stablity

3. Methyl groups: prevent oxidation 4. OEt: Decrease slightly MW, same MDM2 affinity

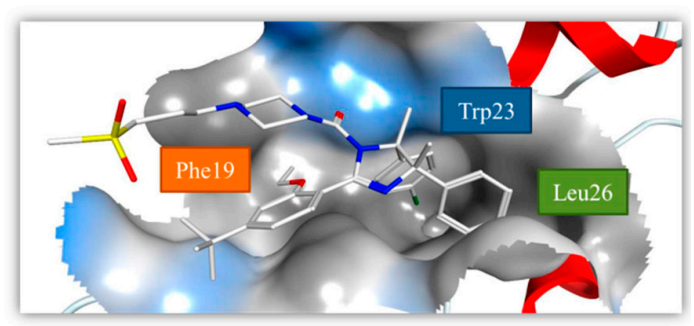

$\Uparrow$

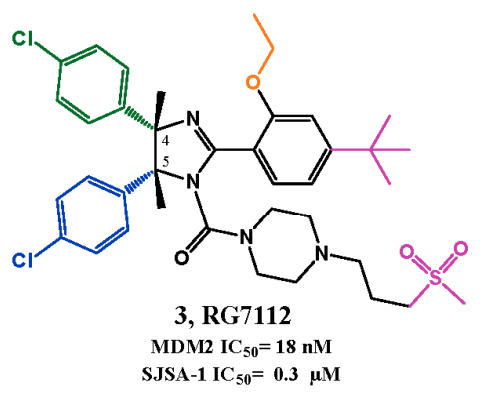<smiles>CCOC(=O)C(C)NC(=O)[C@@H]1C(c2ccc(Cl)cc2)NC(c2ccc(Cl)cc2)C1c1ccc(OC)cc1OC(C)C</smiles>

4

MDM2 $\mathrm{IC}_{50}=0.59 \mu \mathrm{M}$ HCT116 $p 53^{+/+} I_{50}=3.73 \mu \mathrm{M}$

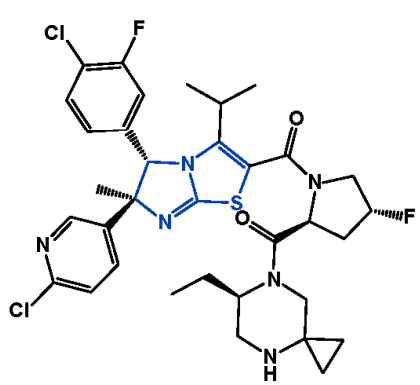

5, DS-5272

$\mathrm{MDM}_{2} \mathrm{IC}_{50}=2.4 \mu \mathrm{M}$ $\mathrm{MDM} 2 \mathrm{IC}_{50}=2.4 \mu \mathrm{M}$
SJSA-1 $\mathrm{IC}_{50}=0.17 \mu \mathrm{M}$

Figure 2. Nutlin scaffold optimization and examples of nutlin derivatizations. Right upper quadrant: crystal structure of compound 3 bound to MDM2 (PDB 4IPF). MDM2 surface is colored in blue for hydrophilic areas and grey for hydrophobic areas. Compound 3 is depicted in stick model and is colored according to element type: white for carbon atoms, blue for nitrogen atoms, red for oxygen atoms, yellow for the sulfur atom, and green for chlorine atoms.

The confirmation of this class of compounds as feasible MDM2 inhibitors evoked a more detailed study in which a library of 22.000 BDP compounds was synthetized and screened using the two methods described above [69]. In 2005, a first SAR study by Johnson \& Johnson gave rise to the lead compound 6 ( $\mathrm{FP} \mathrm{IC}_{50}$ of $0.42 \mu \mathrm{M}$, BrdU JAR IC $50=30 \mu \mathrm{M}$, Figure 3 ). 
The BDP:MDM2 co-crystal structure elucidated the interaction: 1,4-diazepine core gives the necessary rigidity from which the two chlorophenyl groups mimic perfectly Leu26 and Trp23 of p53, while the 7-iodophenyl group inserts in the Phe19(p53) pocket $[68,70]$. Although this last group does not insert as deeply as p53 Phe19 in the pocket, it was later rationalized that this interaction is enhanced because iodine atom makes contacts to the carbonyl group of backbone Gln72 with a strength comparable to a weak hydrogen bond [71]. The initial observation that BDP iodophenyl and p53 Phe19 were not superimposable, gave rise to a rational design of a novel 1,4-diazepine scaffold. In this new scaffold, an increased flexibility was introduced to the fused phenyl-diazepine rings in an attempt to ameliorate the Phe19 mimetic effect, while maintaining the orientation of the two chlorophenyl groups. Unfortunately, although this approach produced new active compounds, the FP $\mathrm{IC}_{50}$ values attained were higher in comparison to the original series (best compound: 7, $\mathrm{FP} \mathrm{IC}_{50}$ of $3.6 \mu \mathrm{M}$ ) [72].

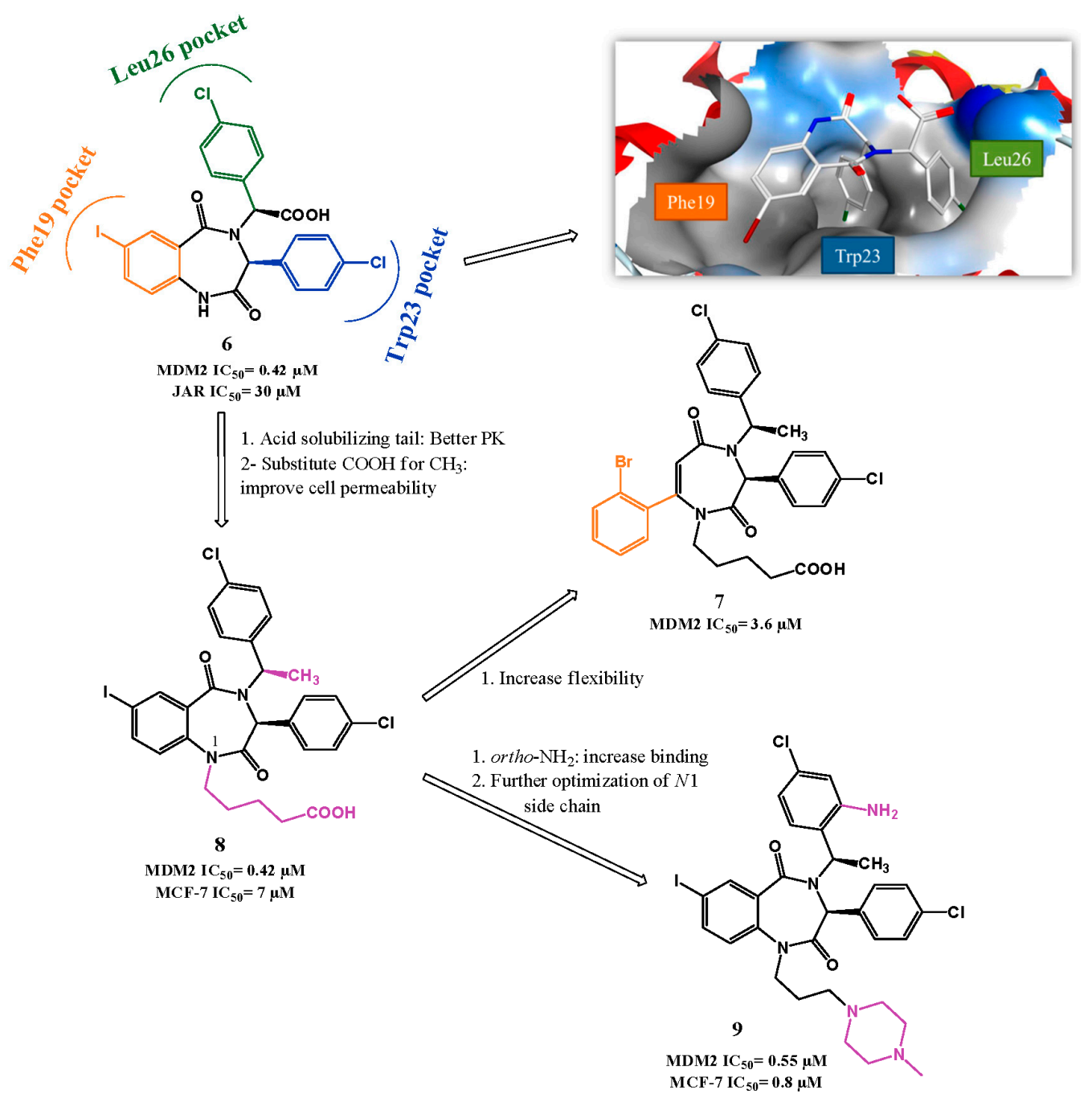

Figure 3. Benzodiazepinediones scaffold optimization. Right upper quadrant: crystal structure of compound 6 bound to MDM2 (PDB 1T4E). MDM2 surface is colored in blue for hydrophilic areas and grey for hydrophobic areas. Compound $\mathbf{6}$ is depicted in stick model and is colored according to element type: white for carbon atoms, blue for nitrogen atoms, red for oxygen atoms, dark red for the iodine atom, and green for chlorine atoms.

Due to the poor PK properties of compound 6, modifications were made to try to improve solubility and permeability. It was rationalized that the inclusion of substituents in N1 might be tolerated since it is primarily solvent-exposed in the co-crystal structure, and also changing the 
carboxylic acid could convey better PK properties to the scaffold. Several solubilizing groups were inserted to N1 and ultimately the pentanoic acid group was selected for further PK optimization. In this study, it was found that the acid group was important to activity, possibly by establishing a hydrogen bond to MDM2 Ser17, and most importantly by placing the chlorophenyl group in the correct orientation through steric repulsion. This repulsion orientation was maintained when carboxylate was substituted with methyl group, while increasing cell permeability $\left(8, \mathrm{FP} \mathrm{IC}_{50}=0.70 \mu \mathrm{M}\right.$, BrdU MCF-7 IC $_{50}=7 \mu \mathrm{M}$ ) [73].

Searching for more potent BDP led to compound 9 bearing an ortho amino group in the $N$-benzylic ring $\left(\mathrm{FP} \mathrm{IC}_{50}=0.55 \mu \mathrm{M}\right.$, BrdU MCF7 $\mathrm{IC}_{50}=0.8 \mu \mathrm{M}$ ) responsible for an additional hydrogen bond established with the carbonyl of MDM2 Val93 [74,75]. Compound 9 was found later to have a synergistic outcome in association with doxorubicin, allowing the visualization of doxorubicin-mediated in vivo activity in a xenograft model at doses that are inactive in monotherapy treatment [76].

More recently, two new scaffolds based on the principle of bioisosterism of BDP have been reported: 1,4 thienodiazepine-2,5-diones (TDZ) [77] and thiobenzodiazepines (Figure 4) [78,79]. For TDZ only a cell-free binding screening has been reported, from which compound 10 emerged as lead compound with a FP Ki of $40 \mu \mathrm{M}$ [77]. The synthesis and biological evaluation of thiobenzo-diazepines showed that the simple replacement of the oxygen by a sulfur atom increased the potency in a FP binding assay, but not in cell-based evaluation. In this SAR study compound 11 emerged as a potential lead compound for future optimization with a FP Ki of $5.34 \mu \mathrm{M}$ and MTT $\mathrm{U}-2 \mathrm{OS} \mathrm{IC}_{50}$ of $1.06 \mu \mathrm{M}$ [78]. Continuation of this work resulted in compounds with better affinity to MDM2, but without cell-based assay improvement [79]. More recently, new benzodiazepine analogues were reported, but again without showing potency improvement (the best derivative, 12, has FP $\mathrm{Ki}=0.2 \mu \mathrm{M}$, MTT U-2OS $\left.\mathrm{IC}_{50}=3.12 \mu \mathrm{M}\right)$ [80]. Furthermore, these new scaffold derivatives did not show selectivity toward cells with wild-type p53 as observed for 1,4-benzodiazepine-2,5-dione derivatives (e.g., compound 9 is 10 times more selective, MCF-7 vs. MDA-MB-231 [75]).
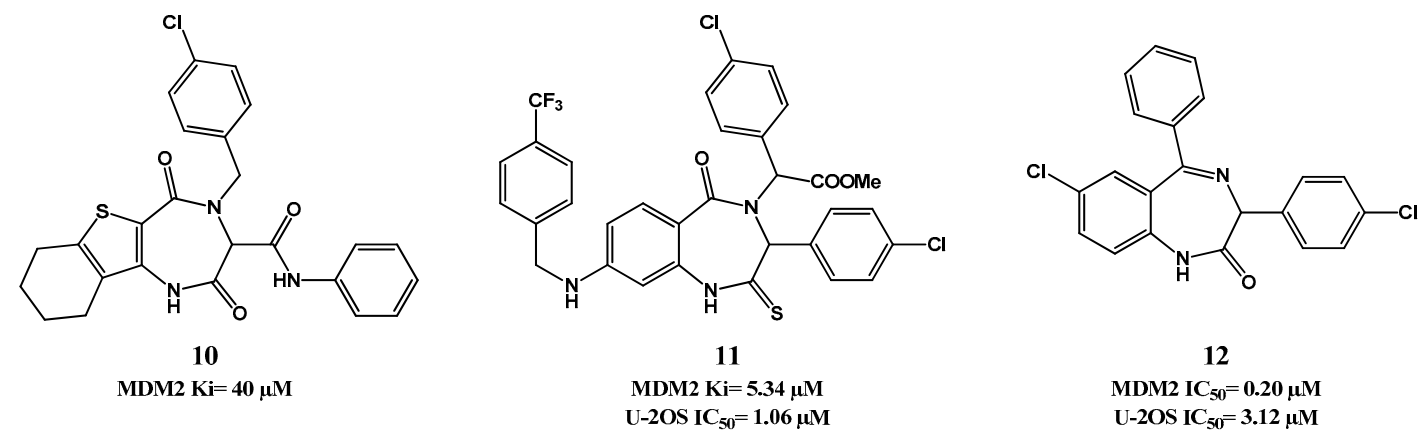

Figure 4. Examples of benzodiazepinedione derivatizations.

Hardcastle et al. described inhibitors of the p53-MDM2 interaction based on an isoindolinone scaffold. Compounds bearing this template (13a,b, Figure 5) were first identified as modest inhibitors of the p53-MDM2 interaction ( $\mathrm{IC}_{50} \sim 200 \mu \mathrm{M}$ ) in an in vitro p53-MDM2 binding assay screening study. In a first optimization, a small compound library focused on the isoindolinone core was synthesized guided by in silico ligand-design, using the published MDM2 crystal structure. Compound 14 emerged as a lead compound with an $\mathrm{IC}_{50}$ of $5.3 \mu \mathrm{M}$ in a cell-free ELISA binding assay. In addition, compound 14 induced a dose-dependent increase of p53 transcriptional activity in the SJSA-1 cancer cell line [81,82]. In this first study, it was suggested that the introduction of different substituents into the isoindolinone template allowed different orientations of the inhibitors in the hydrophobic MDM2 pocket consequently making SAR studies more difficult to interpret. This statement was later corroborated by NMR experiments in which four different binding modes in twelve isoindolinones analyzed were identified, differing only in one group attached to the isoindolinone scaffold [83]. 
Considering the different binding modes and structure information gained by the NMR experiments, compound 15 (ELISA IC $50=15.9 \mu \mathrm{M}$ ) was selected as lead compound for further optimization. The binding mode model of this compound suggested that introducing rigidity to the alkoxy side chain and adding substituents to the $N$-benzyl moiety could favor interaction with MDM2, giving rise to compound 16 (ELISA IC I0 $=0.17 \mu \mathrm{M}$, SRB SJSA-1 $\mathrm{IC}_{50}=5.2 \mu \mathrm{M}$ ) [84,85]. In the last study published by this group attempts to increase potency were made through modifications in the aromatic ring of the isoindolinone core, revealing that the introduction of a 4-chloro in isoindolinone ring improved binding $\left(\mathbf{1 7}(-), \mathrm{IC}_{50}=0.044 \mu \mathrm{M}\right.$, SRB SJSA-1 IC $\left.50=3.7 \mu \mathrm{M}\right)$ [86]. Furthermore contrary to compound 16, compound 17 showed selectivity (3- to 4-fold) towards cells with wild-type p53.<smiles>CCCN1C(=O)c2ccccc2C1(OCc1cc(OC)c(O)c(OC)c1)c1ccc(Cl)cc1</smiles>

14

MDM2 $\mathrm{IC}_{50}=5.3 \mu \mathrm{M}$

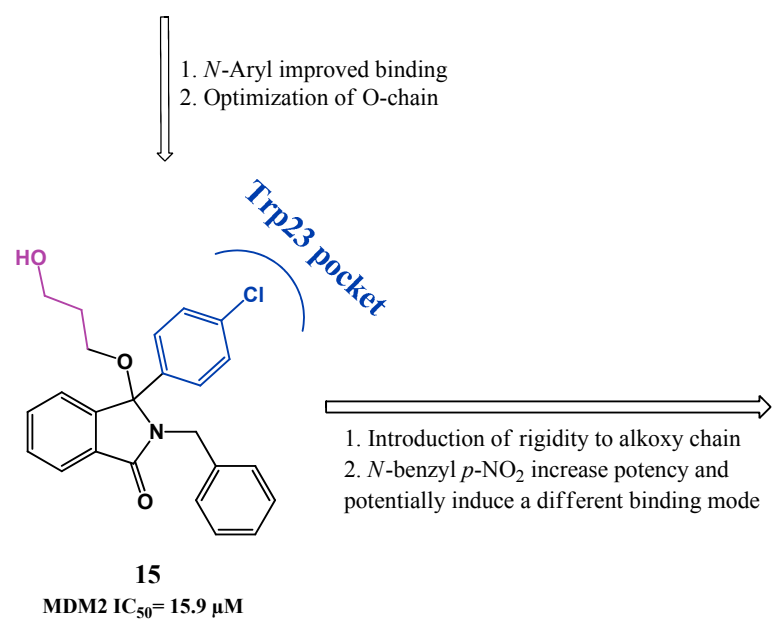

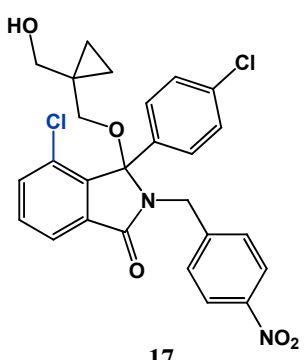

(-): MDM2 $\mathrm{IC}_{50}=44 \mathrm{nM}$ SJSA-1 IC $\mathrm{IC}_{50}=3.7 \mu \mathrm{M}$

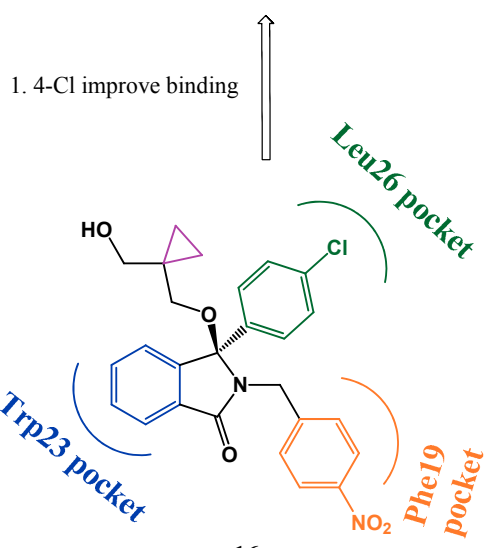

16

MDM2 $\mathrm{IC}_{50}=0.17 \mu \mathrm{M}$ SJSA-1 IC $\mathrm{IC}_{50}=5.2 \mu \mathrm{M}$

Figure 5. Isoindolinone scaffold optimization. Representations of binding modes were determined from chemical shift data and molecular docking [83,85].

Recently, phenylalaninol-derived oxazoloisoindolinone 18, containing a more rigid structure, was identified as a potential p53-MDM2 interaction inhibitor inducing a p53-dependent activation in vitro leading to apoptosis (SRB HCT116 $p 53^{+/+} \mathrm{IC}_{50}=9.7 \mu \mathrm{M}$, Figure 6) [87].

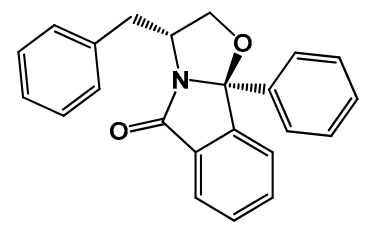

18

$\mathrm{HCT116} p 53^{+/+} \mathrm{IC}_{50}=9.7 \mu \mathrm{M}$

Figure 6. Oxazoloisoindolinone derivative 18. 
Chromenotriazolopyrimidines were found by Amgen to be inhibitors of p53-MDM2 in a HTRF-based high throughput screen of about 1.4 million compounds, and their binding to MDM2 was confirmed by SPR. From this screening hit compound 19 (Figure 7) emerged [88]. Only the syn-(6R,7S) isomer was found to be active (HTRF $\left.\mathrm{IC}_{50}=1.23 \mu \mathrm{M}\right)$. Co-crystallization of 19 with MDM2 showed that the chromenotriazolopyrimidine is a fairly rigid scaffold from which two para-bromophenyl groups at C-6 and C-7 in a syn relationship interact with MDM2 in the Trp23 ${ }_{(p 53)}$ and Leu26 $(p 53)$ pockets, respectively. Furthermore the C-7 aromatic group also establishes a weak $\pi$-stacking interaction with the His96 side chain of MDM2. The third key p53 amino acid Phe19 is mimicked by the chromene D ring. However, these compounds were chemically unstable and individual diastereoisomers tended to equilibrate, forming mixtures consisting mostly of the more stable anti diastereoisomers. This problem was overcome by N11-methylation, which prevented racemization without affecting the potency. Optimization of the lead compound was attempted by introducing variability to the three phenyl rings involved in the binding. Introduction of a methoxy group in position 1 gave the best cell-free activity $\left(20\right.$, HTRF $\left.\mathrm{IC}_{50}=0.20 \mu \mathrm{M}\right)$. However, it is believed that this improved activity is product of the molecule core torsion due to N-methyl and C1-methoxy proximity that allows a better pocket fitting rather than a improve interaction to the protein by the methoxy group [88].

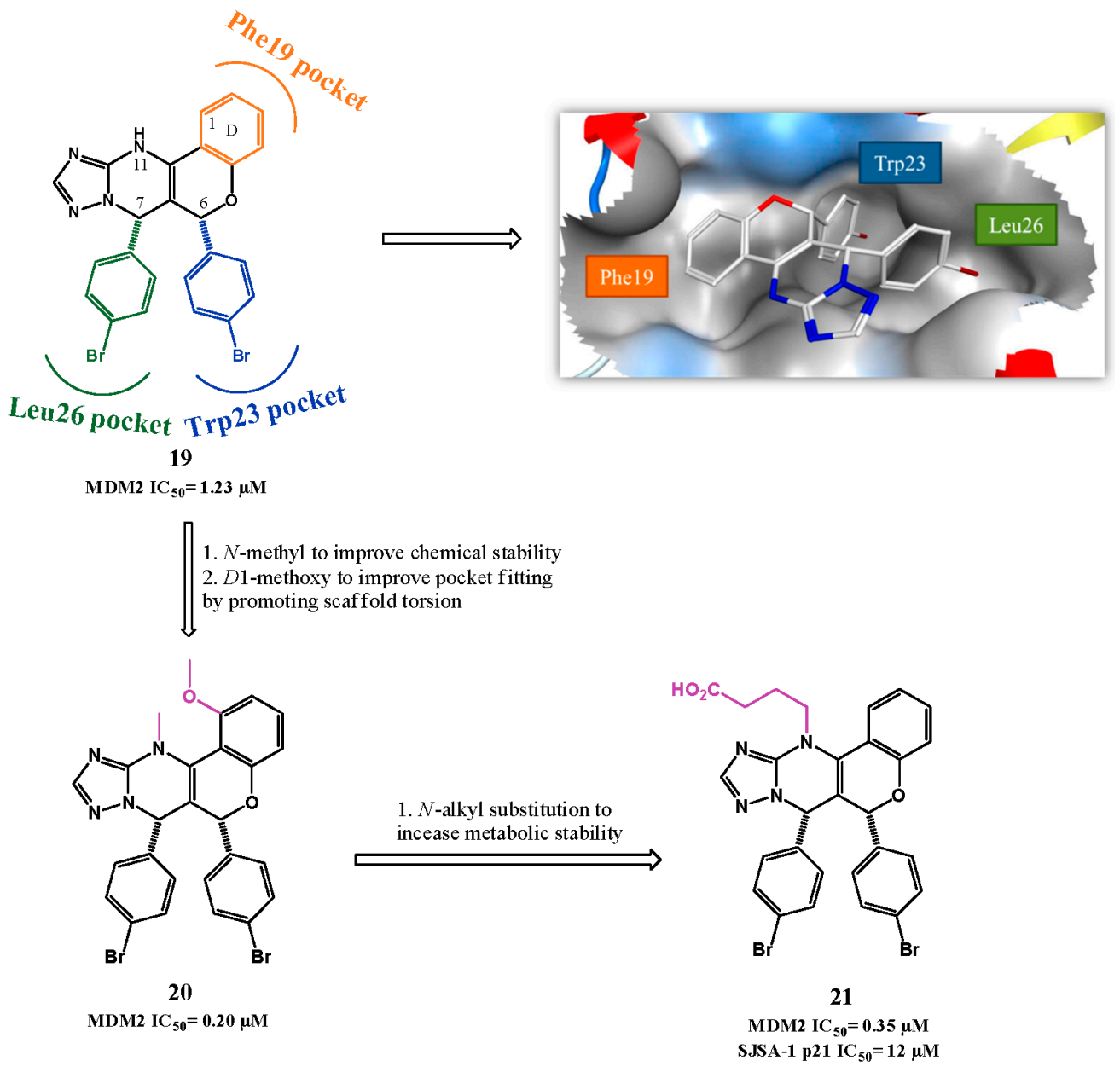

Figure 7. Chromenotriazolopyrimidine scaffold optimization. Right upper quadrant: crystal structure of compound 19 bound to MDM2 (PDB 3JZK). MDM2 surface is colored in blue for hydrophilic areas and grey for hydrophobic areas. Compound $\mathbf{1 9}$ is depicted as a stick model and is colored according to element type: white for carbon atoms, blue for the nitrogen atom, red for the oxygen atom, and dark red for bromine atoms. 
To enhance PK properties, especially problems observed with metabolic stability hypothesized due to rapid $\mathrm{N}$-demethylation and consequent tautomeric isomerization, SAR studies were performed at the $N$-substituent. It led to compound 21 (HTRF IC $50=0.35 \mu \mathrm{M}$, SJSA-1 p21 IC $50=12 \mu \mathrm{M}$ ), with increase metabolic stability [89].

Taking in consideration that p53 Trp23 side chain (indole group) seems to be critical for p53-MDM2 interaction, by burying deep inside p53 hydrophobic pocket and establishing a hydrogen bond $(\mathrm{NH})$ to the MDM2 backbone (carbonyl), the oxindole moiety was believed to perfectly mimic this residue. Moreover since many natural anticancer products, such as spirotryprostatin A and alstonisine, have a spirooxindole main core, it was rationalized and later corroborated by in silico studies that the spiropyrrolidine ring could provide the necessary rigidity to the spirooxindole scaffold, from which two extra hydrophobic groups could be projected in the required orientation to mimic the other two residues of p53. From this structure-based design an initial lead compound arose in 2005 (22, Figure 8) with a FP Ki of $8.46 \mu \mathrm{M}$ (Wang group, University of Michigan). Computational modeling suggested that optimization could be achieved by varying the isobutyl substituent and by introducing small substituents in the meta-position of the phenyl ring (room in Leu26 ${ }_{(p 53)}$ and Phe19 ${ }_{(p 53)}$ pocket respectively still available). Therefore, structure-activity relationship (SAR) studies led to MI-43 (23, FP $\mathrm{Ki}=86 \mathrm{nM}$, WST-8 $\mathrm{LNCaP} \mathrm{IC}_{50}=0.83 \mu \mathrm{M}$ ). This compound also showed good selectivity over normal cells and cancer cells with deleted p53 [90].

Further in silico investigation into the interaction of compound 23 and p53 with MDM2, suggested that a possible fourth residue (Leu22) could be mimicked. The Leu22(p53) pocket is partially exposed to solvent and therefore mimicking this residue could result not only in an increase of potency but also in PK improvement, since it could allow the presence of polar groups. A second round of SAR studies was devised, having mainly this observation in consideration, leading to MI-63 (24) with a 2-morpholin-4-yl-ethylamine group. Docking studies revealed that not only this side chain could mimic Leu22 but the morpholine oxygen could possibly interact by $\mathrm{H}$ bonding with Lys 90 in MDM2 (mimicking p53 Glu17). Furthermore the introduction of a fluorine atom in the phenyl group, a frequently effective strategy to increase metabolic stability, augmented the potency (FP $\mathrm{Ki}=3 \mathrm{nM}$, WST-8 LNCaP IC $50=0.28 \mu \mathrm{M})[91,92]$. However, due to the fact that compound 24 had only a modest oral bioavailability, additional investigations, especially on the polar morpholinyl substituent were performed. It was found that changing to a butyl-1,2-diol significantly improved PK (MI-219: 25, FP Ki $=13.1 \mathrm{nM}$, WST-8 SJSA-1 $\mathrm{IC}_{50}=0.7 \mu \mathrm{M}$ and MI-147: 26, FP Ki $=0.6 \mathrm{nM}$, WST-8 SJSA-1 IC $_{50}=0.2 \mu \mathrm{M}$ ) [93]. Nevertheless these new derivatives still required high oral doses (200-300 $\mathrm{mg} / \mathrm{kg}$ ) to achieve tumor growth inhibition in mice xenograft models, and most important a complete tumor regression remained elusive [94]. More recently this last goal was attained with MI-888 (27, FP Ki $=0.44 \mathrm{nM}$, WST-8 SJSA-1 $\left.\mathrm{IC}_{50}=0.08 \mu \mathrm{M}\right)$ [95] and MI-77301/SAR405838 (28, FP Ki $=0.88 \mathrm{nM}$, WST-8 SJSA-1 IC $50=0.092 \mu \mathrm{M}$ ) [96]. These compounds were synthesized in a new series of optimizations that continued to focus on the $5^{\prime}$ pyrrolidine tail chain, especially by introducing conformational constrain, while attempting to increase metabolic stability [95].

Recently it was discovered that some of these spiropyrrolidine oxindoles can suffer reversible ring-opening and cyclization of the pyrrolidine ring in protic solution, giving rise to different stereoisomers with different binding affinities to MDM2 [97]. Therefore, in 2015, a second generation of spirooxindoles emerged that possess symmetrical substituents at $\mathrm{C}^{\prime}$ position of the pyrrolidine ring that allow a rapid and irreversible conversion to the most active diastereoisomer (MI-1061: 29, FP Ki $=0.16 \mathrm{nM}$, WST-8 SJSA-1 $\mathrm{IC}_{50}=0.10 \mu \mathrm{M}$ ) [98]. Compounds 27 and 28 from the first generation were already synthesized having in consideration the desired stereochemistry. Interestingly the best diastereomer revealed a different and better binding to MDM2 with the neopentyl and phenyl ring occupying now Phe19 ${ }_{(p 53)}$ and Leu26 $(p 53)$ pockets respectively (Figure 8 , represented for compound 26). Furthermore their side chain carbonyl is capable of establishing a $\mathrm{H}$ bond with the imidazole side chain of His96 and the terminal hydroxyl group with the Lys94 side chain [96].

Compound 28 advanced into clinical trials in 2012 sponsored by Sanofi. It displays more than 100-fold selectivity over cell lines with mutated or deleted p53, activating a p53-dependent pathway leading to cell-cycle arrest and/or apoptosis in cancer cells in vitro and in vivo xenograft tumor models. 
A complete tumor regression was achieved at $100 \mathrm{mg} / \mathrm{kg}$ with a daily dose for 9 days and at $200 \mathrm{mg} / \mathrm{kg}$ with a single oral dose in SJSA-1 mice xenograft [96].

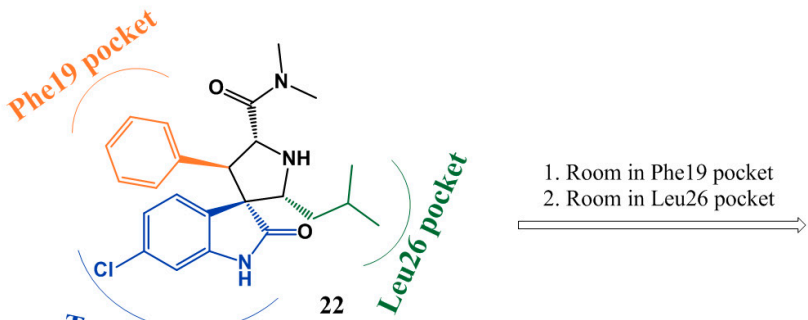

$$
\text { Trp23 pocket } \begin{array}{r}
\text { MDM2 Ki= }=8.46 \mu \mathrm{M} \\
\mathrm{LNCaP} \mathrm{IC}_{50}=9.7 \mu \mathrm{M}
\end{array}
$$

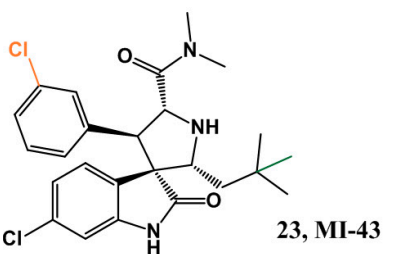

1. Optimization of amide
improve binding and PK

2- Introduction of F: increase PK

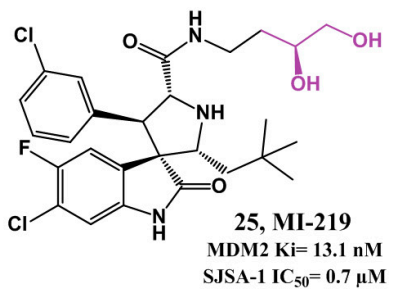

1. Further optimization

of amide side chain

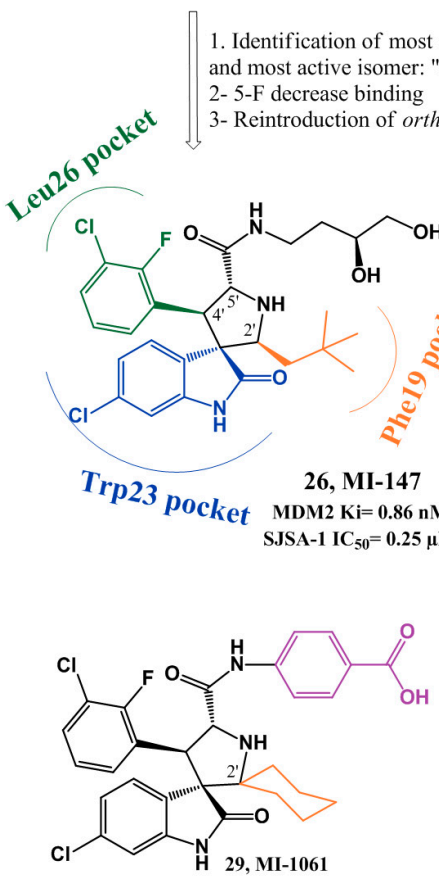

1. Further optimization of amide side chain
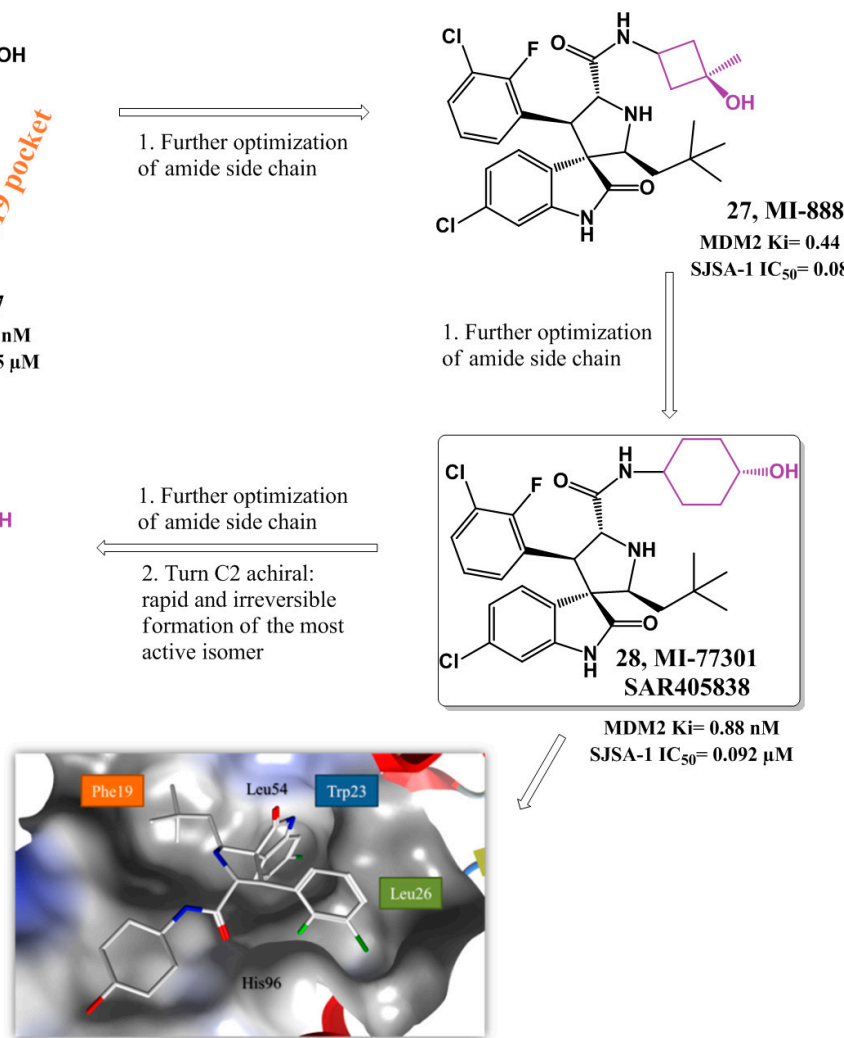

1. Further optimization of amide side chain

2. Turn $\mathrm{C} 2$ achiral: rapid and irreversible formation of the most active isomer

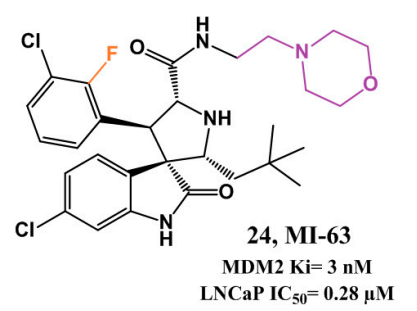

MDM2 $\mathrm{Ki}=0.44 \mathrm{nM}$ of amide side chain

MDM2 $\mathrm{Ki}=0.88 \mathrm{nM}$

MDM2 $\mathrm{Ki}=86 \mathrm{nM}$

LNCaP IC ${ }_{50}=0.83 \mu \mathrm{M}$ SJSA-1 IC $_{50}=0.08 \mu \mathrm{M}$

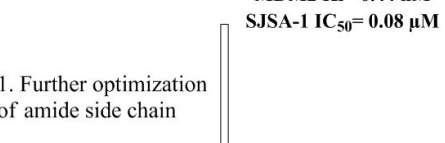

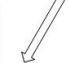

$\mathrm{K} 2 \mathrm{Ki}=4.4 \mathrm{nM}, \mathrm{IC}_{50}=0.1$
SJSA-1 $\mathrm{IC}_{50}=0.10 \mu \mathrm{M}$

Figure 8. Spiropyrrolidine scaffold optimization. Docking pose of compound 28 in MDM2 (PDB 3LBL). MDM2 surface is colored in blue for hydrophilic areas and grey for hydrophobic areas. Compound 28 is depicted in stick model and is colored according to element type: white for carbon atoms, blue for nitrogen atoms, red for oxygen atoms, bright green for fluorine, and dark green for chlorine atoms. 
In 2014, Hoffmann-La Roche published two other papers describing further optimizations of spiro[oxindole-3,3'-pyrrolidines], having in consideration the beneficial PK and potency improvement obtained when a phenyl derivative group is attached to the amide side chain. RO8994 (30, HTRF $\mathrm{IC}_{50}=5 \mathrm{nM}$, SJSA-1 $\mathrm{IC}_{50}=13 \mathrm{nM}$, Figure 9) emerged in a SAR study focused especially in additional modifications to this side chain $[99,100]$. Bioisosteric substitution of the 6-chlorooxindole moiety led to compounds RO2468 (31, HTRF IC $50=6 \mathrm{nM}$, MTT SJSA-1 IC $50=3 \mathrm{nM}$ ), and RO5353 (32, HTRF IC $50=7 \mathrm{nM}$, MTT SJSA-1 $\left.\mathrm{IC}_{50}=2 \mathrm{nM}\right)$. Although the in vitro and in vivo activities were comparable to those of RO8994, these compounds showed improved selectivity between wt p53 cell lines and mut p53 cell lines [101].

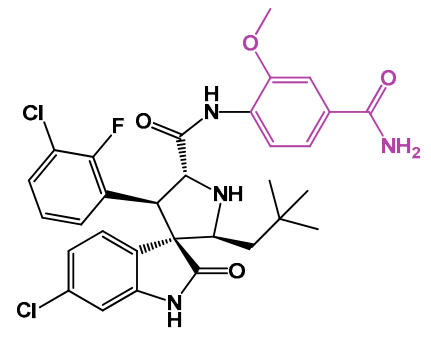

30, RO8994

MDM2 IC $50=5 \mathrm{nM}$ SJSA-1 IC $_{50}=13 \mathrm{nM}$

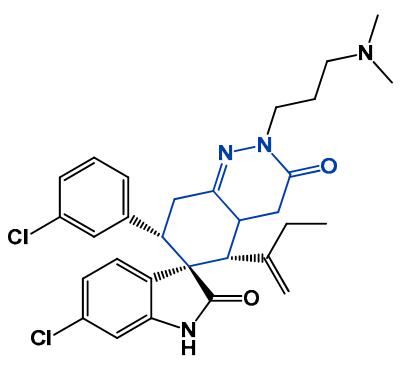

33

MDM2 IC $\mathrm{In}_{50}=0.1 \mu \mathrm{M}$

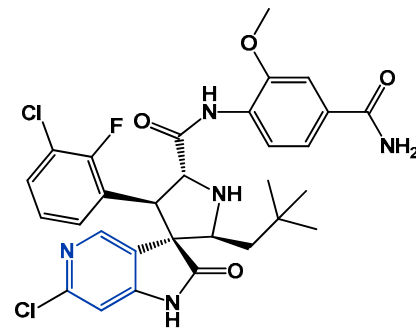

31, RO2468

MDM2 $\mathrm{IC}_{50}=6 \mathrm{nM}$ SJSA- 1 IC $_{50}=3 \mathrm{nM}$

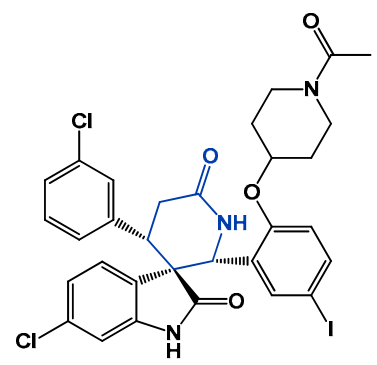

34

MDM2 $\mathrm{IC}_{50}=34 \mathrm{nM}$

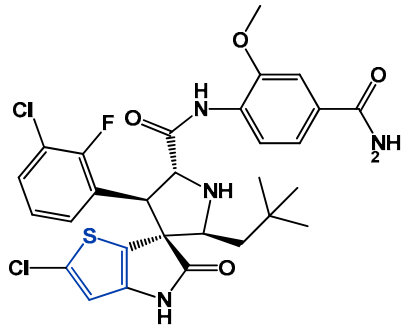

32, RO5353

MDM2 $\mathrm{IC}_{50}=7 \mathrm{nM}$

SJSA-1 IC I0 $_{50}=2 \mathrm{nM}$

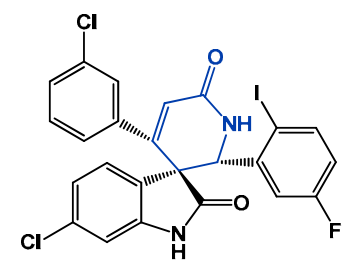

35

MDM2 $\mathrm{IC}_{50}=66 \mathrm{nY}$

Figure 9. Spiropyrrolidines and others spiro-heterocyclic-oxindole derivatives.

Several patents have emerged from Hoffmann-La Roche during the last 10 years covering spiro[oxindole-3,3'-pyrrolidines] and other spiro-heterocyclic-oxindole based compounds (e.g., 33, 34 and 35) that inhibit the p53-MDM2 interaction $[39,42,65]$.

In 2010, Gomez-Monterrey et al. synthesized a series of spiro[oxindole-3,3'-thiazolidines], with ISA27 emerging as the most potent derivative in cell lines (36, MTT U937 $\mathrm{IC}_{50}=0.87 \mu \mathrm{M}$, Figure 10). Destabilization of p53-MDM2 interaction by compound $\mathbf{3 6}$ was established first by NMR analysis (AIDA method) [102], and later complemented by an in depth in vitro validation in human glioblastoma multiforme [103].

A second round of SAR studies was focused on opening the ISA27 imidazole ring in an attempt to increase structural diversity and introduce extra potential binding points. This was anticipated to allow a better fitting into the p53 pocket, since ISA27 most likely only mimics two of the three pivotal p53 amino acids [104]. SM13 (37, MTT MCF-7 IC I0 $=0.04 \mu \mathrm{M})$ emerged from this study. Docking studies suggested that the 3-cyclohexylcarboxy moiety occupies the Trp23 ${ }_{(p 53)}$ pocket, and the ethyl ester side chain the Phe19 ${ }_{(p 53)}$ pocket. The Leu26 $6_{(p 53)}$ pocket is only slightly occupied by the oxindole ring, but the authors suggested that this drawback seems to be somewhat compensated by extra hydrophobic interactions gained through the N1-methyl group. In vitro inhibition of p53-MDM2 interaction was evaluated for both compounds using an ELISA binding assay. At $5 \mu \mathrm{M}$ ISA27 (36) and SM13 (37) inhibited $25 \%$ and $30 \%$ of the interaction respectively (nutlin-3 inhibited $19 \%$ ). However, both compounds were also effective in cancer cell lines with mutated p53. A detailed study to clarify 
the mechanism of action of SM13 suggested that besides inhibiting p53-MDM2 interaction, this compound acts in a manner strictly dependent on p53. No apoptosis induction was observed in FRO cells (null p53) and only activation of p53-dependent mitochondrial apoptotic pathway was observed in Kat-4 (mut p53) due to its lack of p53 transcriptional activity [105].

More recently, Kumar et al. reported spiro[oxindole-3,2'-pyrrolidines] that seemed to modulate p53 in vitro and in vivo [106]. However, the compounds did not show selectivity between breast cancer cell lines with wt p53 (MCF-7) and mut p53 (MDA-MB-231), and although an increase in MDM2 levels was observed, no studies were focused in the p53-MDM2 interaction (38, MTT MCF-7 IC $50=6.5 \mu \mathrm{M}$, Figure 10). Also, Ivanenkov et al. reported dispiro compounds with a spiropyrrolidine oxindole moiety that can potentially interfere with p53-MDM2 interaction by in silico comparison with known MDM2 antagonists (39, MTT MCF-7 IC $50=4.88 \mu \mathrm{M}$ ) [107]. Our research group has also recently developed a family of spiroisoxazoline oxindoles, structural analogues of spirooxindole pyrrolidines, in order to identify new MDM2 inhibitors. The compounds were shown to induce cell death by apoptosis and to inhibit the p53-MDM2 interaction in a cell-based assay $[108,109]$. Following this work, we synthesized a family of spirooxadiazoline oxindoles in which the spiroisoxazoline carbon C- $4{ }^{\prime}$, with tetrahedral molecular geometry, is substituted by a nitrogen atom. Nine compounds showed an antiproliferative activity in cell lines below $10 \mu \mathrm{M}$, and four compounds were more active than the positive control nutlin-3a in HCT 116 p53 $3^{(++)}$cell line. Moreover, they were shown to induce p53 stabilization and transactivation, to induce apoptosis, and to inhibit the interaction between p53 and MDM2 in a live-cell bimolecular fluorescence complementation assay. Compound $\mathbf{4 0}$ was one of the most potent compounds in the HCT 116 p53 $3^{(++)}$cell line (MTS HCT-116 p53 ${ }^{(+/+)} \mathrm{IC}_{50}=1.7 \mu \mathrm{M}$, Figure 10) [110]. Furthermore, we developed a library of spiropyrazoline oxindoles, containing a five membered ring (pyrazoline) with one more aromatic substituent (the oxygen atom in the isoxazoline ring was replaced by a $N$-Ar group) to develop more potent anti-cancer agents. The compounds were evaluated against the MCF7 breast cancer cell line. The most active compounds had activities around $7 \mu \mathrm{M}$, and were selective over MDA-MB-231 tumor cells and non-cytotoxic against Hek 293T non-tumor cells [111,112].

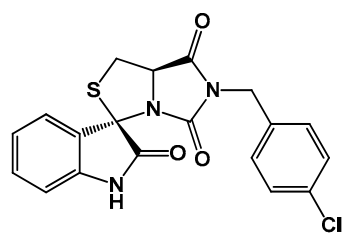

ISA27, 36 $\mathrm{U}_{937} \mathrm{IC}_{50}=0.87 \mu \mathrm{M}$

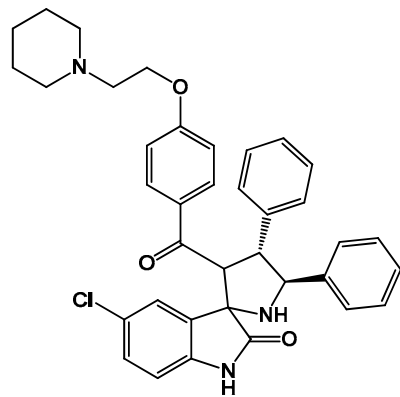

38 MCF-7 $\mathrm{IC}_{50}=6.5 \mu \mathrm{M}$
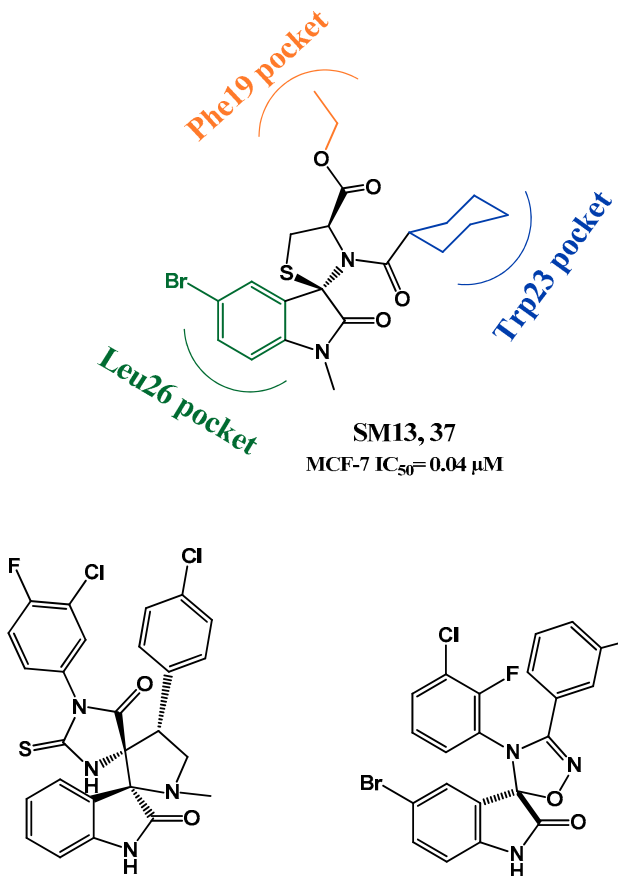

39

MCF-7 $\mathrm{IC}_{50}=4.88 \mu \mathrm{M}$

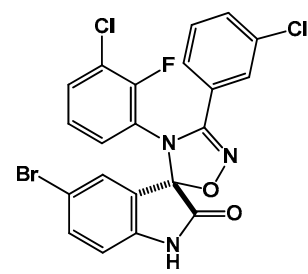

40

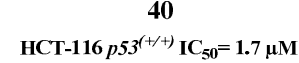

Figure 10. Spiropyrrolidine, spirothiazolidine, and spirooxadiazoline oxindole derivatives with anti-cancer activity. 
Compounds detaining an imidazole-indole scaffold were simultaneously and independently developed by Novartis and the University of Pittsburgh [113,114]. Compounds WK23 (41, FP $\mathrm{IC}_{50}=1.71 \mu \mathrm{M}$, Figure 11) and WK298 $\left(42, \mathrm{FP} \mathrm{IC}_{50}=0.19 \mu \mathrm{M}\right)$ emerged as p53-MDM2 interaction inhibitors. The two molecules only differ by the substituent attached to position 2 of the 6-chloroindole moiety and consequently the central core that mimics p53 is the same. As already observed for other MDM2 inhibitors, a co-crystal structure reveal that the 6-chloroindole ring mimics the p53 Trp23 with the 6-chloro substituent enhancing the interaction by penetrating deeply in the pocket. Moreover, the indole nitrogen atom forms a hydrogen bond with Leu54. The para-chlorobenzyl group fills the Leu26 pocket and the phenyl group interacts with the Phe19 ${ }_{(p 53)}$ pocket. The additional tail in 42 enhances not only PK properties, but also protects the Phe19 ${ }_{(p 53)}$ pocket from solvent [114].

The recognition that an indole/oxindole moiety function was an excellent Trp23 mimetic moiety gave rise to several other potential good compounds (e.g., 43, FP $\mathrm{Ki}=400 \mathrm{nM}$ and 44, HTRF IC $50=1.16 \mathrm{nM})[65,115]$.

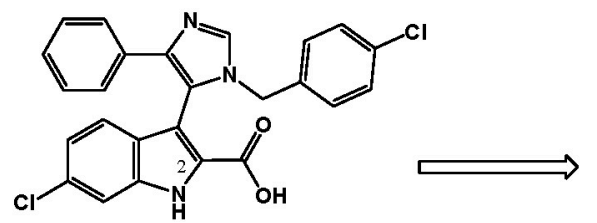

41, WK23

MDM2 $\mathrm{IC}_{50}=1.71 \mu \mathrm{M}$

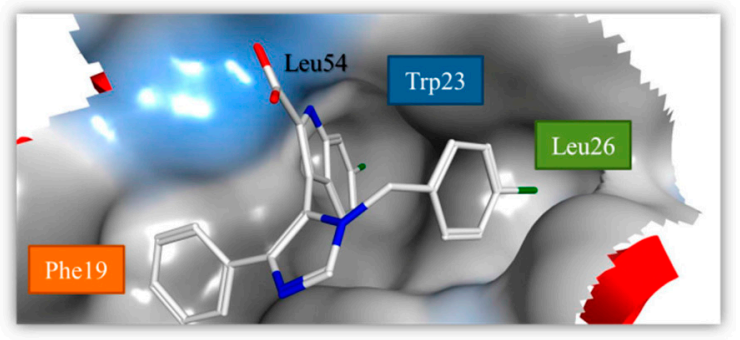

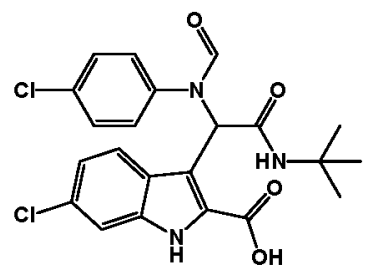

43

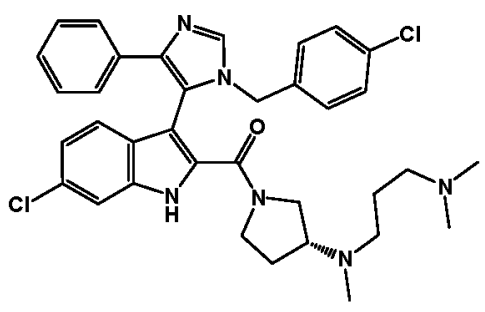

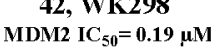

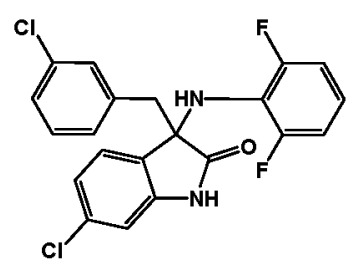

$\stackrel{44}{\operatorname{MDM} 2 \mathrm{IC}_{50}=1.16 \mathrm{nM}}$

Figure 11. Indolyl derivatives. Right upper quadrant: structure of compound 41 bound to MDM2 (PDB 1YCR). MDM2 surface is colored in blue for hydrophilic areas and grey for hydrophobic areas. Compound 56 is depicted in stick model and is colored according to element type: white for carbon atoms, blue for nitrogen atoms, red for oxygen atoms, and green for chlorine atoms.

RG7388 from Hoffman-La Roche (45, Figure 12) was designed based on the spiropyrrolidine oxindole MI-219 structure 25 and considering that an aromatic moiety would be better to mimic the Leu26 of p53. The presence of a nitrile group would favor the necessary "trans-trans" configuration (between rings A and B, and ring A and neopentyl group, Figure 12) required for better interaction with MDM2. Optimization to RG7388 was mainly focused on the amide side chain of compound 46 $($ HTRF IC $50=74 \mathrm{nM}$, MTT SJSA-1 IC $50=2.1 \mu \mathrm{M})$. Compound 45, with a methoxy para-benzoic acid moiety, was the most potent derivative with the best PK properties (45, HTRF IC $50=6 \mathrm{nM}$, MTT SJSA-1 $\left.\mathrm{IC}_{50}=10 \mathrm{nM}\right)$. Furthermore, the addition of fluorine to both phenyl rings also contributed to increase binding to MDM2. RG7388 exhibited more than 100-fold selectivity over cell lines with mutated p53, activated the p53 pathway, promoted tumor regression at $25 \mathrm{mg} / \mathrm{kg}$ with daily doses in SJSA- 1 mice xenograft $[116,117]$ and is currently in clinical trials. 


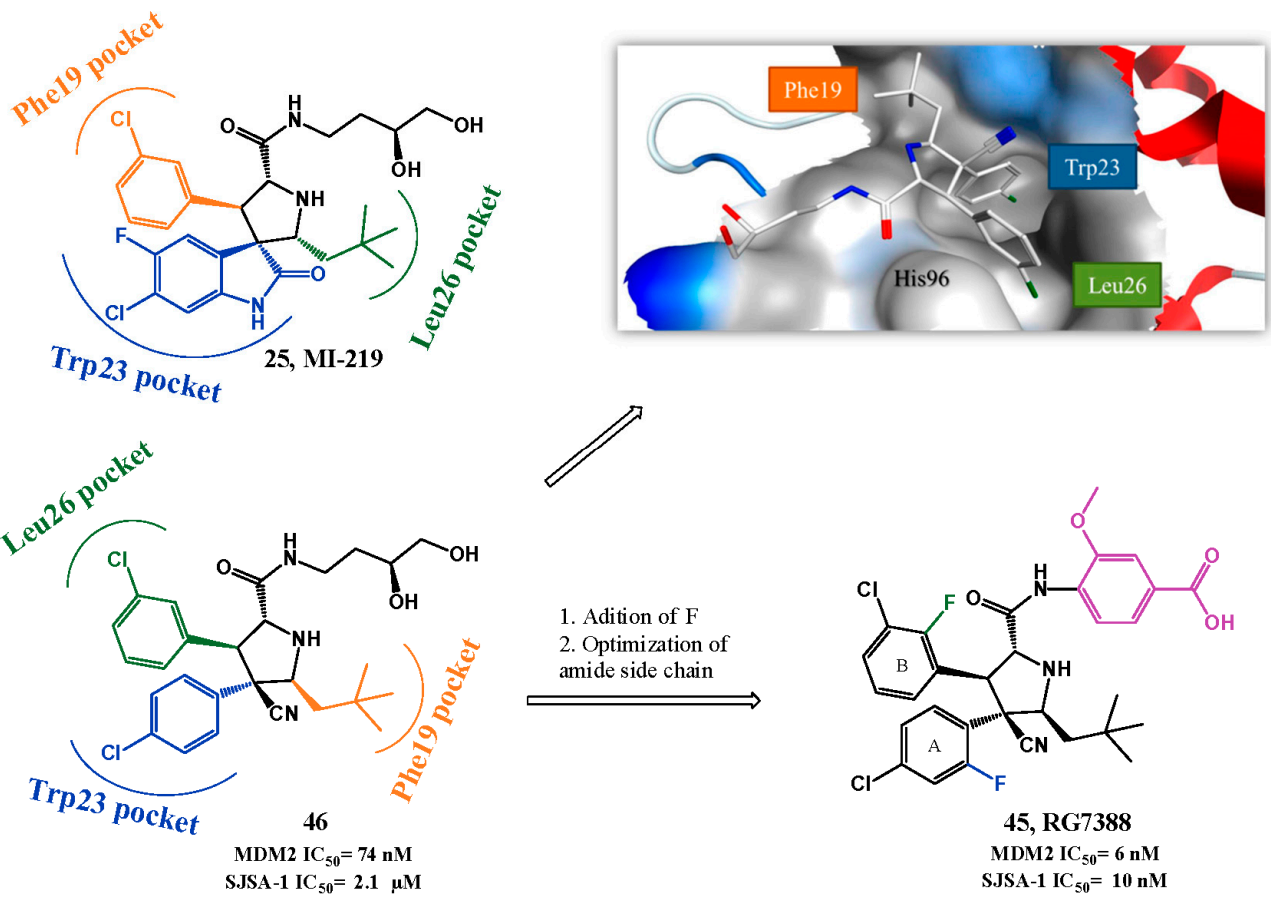

Figure 12. Pyrrolidine-2-carboxamide scaffold optimization. Right upper quadrant: crystal structure of compound 46 bound to MDM2 (PDB 4JRG). MDM2 surface is colored in blue for hydrophilic areas and grey for hydrophobic areas. Compound $\mathbf{4 6}$ is depicted in stick model and is colored according to element type: white for carbon atoms, blue for nitrogen atoms, red for oxygen atoms, and green for chlorine atoms.

In 2012, morpholinones were described by Amgen as p53-MDM2 interaction inhibitors (47, HTRF IC $_{50}=2.0 \mu \mathrm{M}$, Figure 13) [118,119]. A co-crystal structure of 47 with MDM2 showed that the 6- and 5-para-bromophenyl rings occupy Phe19 ${ }_{(p 53)}$ and Trp23 ${ }_{(p 53)}$ pockets, respectively. Unfortunately the benzyl group was not projected into the Leu26 $6_{(p 53)}$ pocket and instead it interacted with the Phe55 residue in a shallow hydrophobic shelf region. In an attempt to mimic the Leu26 residue, the para-halogen was replaced by a meta-halogen on the C6 phenyl ring, leading to a $180^{\circ}$ rotation of the morpholinone in the p53 pocket $[59,96]$. A proper $N$-alkyl substituent would fill the Phe19 pocket $\left(48\right.$, HTRF $\left.\mathrm{IC}_{50}=1.8 \mu \mathrm{M}\right)$. An additional SAR study at the $\mathrm{C} 2$ position revealed that an acetic acid moiety increased potency by establishing an electrostatic interaction with the His 96 residue of MDM2 $\left(49\right.$, HTRF IC $_{50}=0.3 \mu \mathrm{M}$, EdU SJSA-1 IC $\left.50=15.7 \mu \mathrm{M}\right)$. However due to the fact that the proximity of this carboxylic acid to morpholinone oxygen could possibly generate electrostatic repulsion and consequently destabilize the right binding conformation, the latter was substituted with a methylene group. This alteration created more potent derivatives, involving now a piperidinone core. Studies of the stereochemical configuration revealed that stereoisomer $\mathbf{5 0}$ was the most potent derivative $\left(\right.$ HTRF IC $\mathrm{I}_{50}=34 \mathrm{nM}$, EdU SJSA-1 IC $\left._{50}=3.35 \mu \mathrm{M}\right)[118,120]$.

The next optimizations focused primarily in conformational controls to make sure that the best conformation was favored. In the best binding pose, the $N$-substituent needs to adopt a syn ("downward") orientation in regards to the para-chlorophenyl group to properly occupy the Phe19(p53) pocket. However, since the alternative anti conformation is more stable, it was envisaged that introducing a "directing" group at the $\alpha$-carbon to the piperidinone nitrogen could properly direct the desired group into the pocket. Another important orientation aspect observed in the binding conformation is the necessity of C5 and C6 aryl groups to adopt a gauche-like orientation instead of the more stable anti-like orientation. For that, introducing another substituent at $\mathrm{C} 3$ position could create a 1,3-steric repulsion to the anti-like orientation, favoring the desired one (51, HTRF $\mathrm{IC}_{50}=2.2 \mathrm{nM}$, EdU SJSA-1 IC $50=190 \mathrm{nM})[119,121]$. 


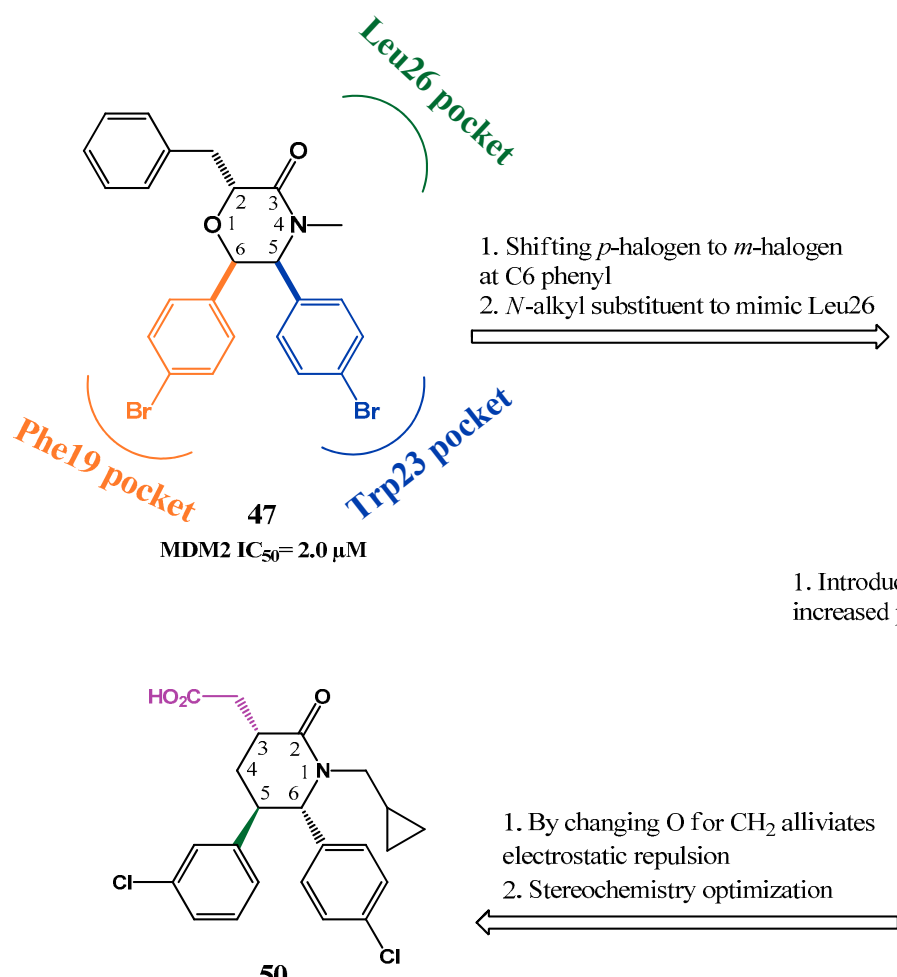

MDM2 IC $_{50}=34 \mathrm{nM}$

SJSA-1 $\mathrm{IC}_{50}=\mathbf{3 . 3 5} \mu \mathrm{M}$

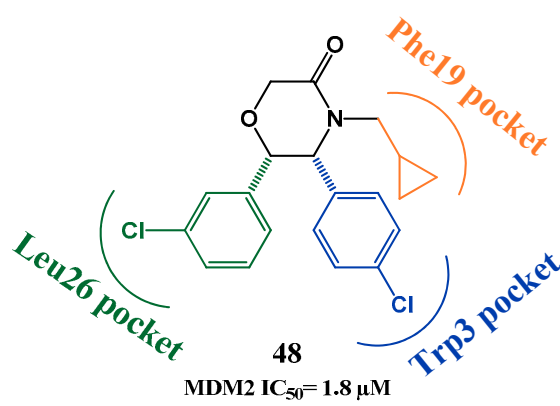

Introducing acetic acid moiety increased potency
2. Stereochemistry optimization of $N$-alkyl chain

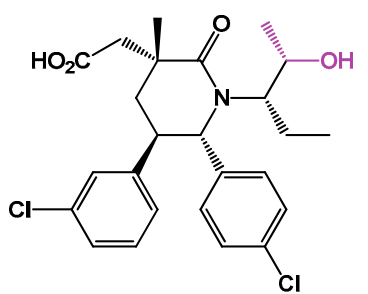

52, AM-8553

MDM2 IC $_{50}=1.1 \mathrm{nM}$ SJSA-1 IC $_{50}=68 \mathrm{nM}$

MDM2 $\mathrm{IC}_{50}=2.2 \mathrm{nM}$

SJSA-1 IC I0 $_{50}=190 \mathrm{nM}$
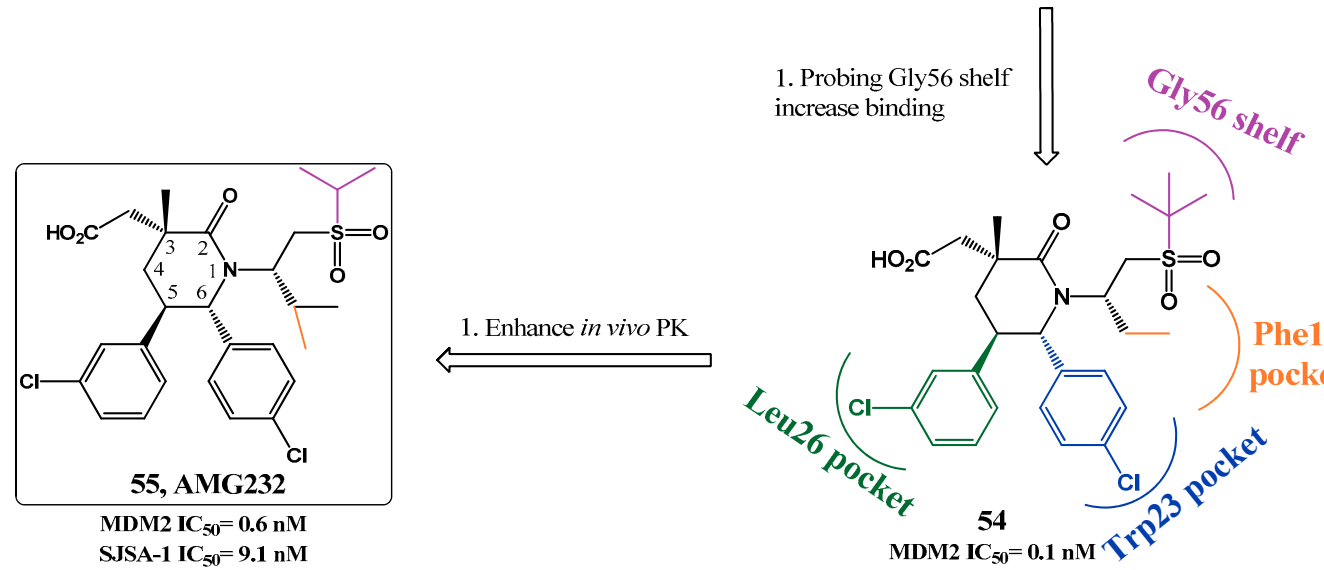

1. Enhance in vivo $\mathrm{PK}$
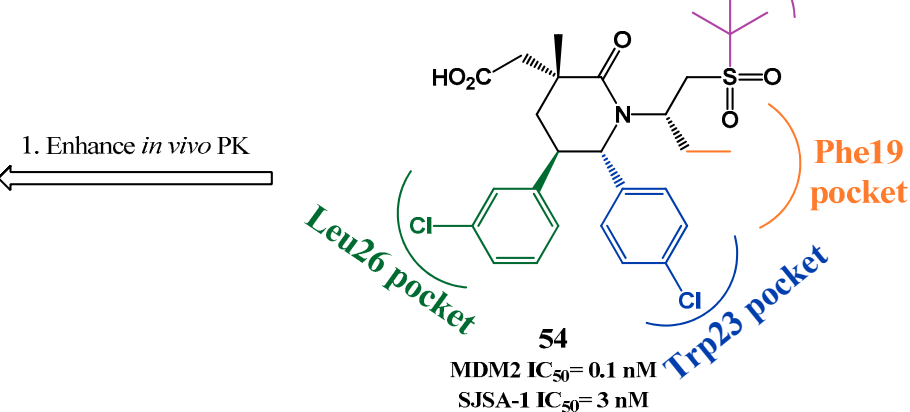

Figure 13. Piperidinone scaffold optimization to AMG232. 
In an attempt to improve the PK properties further optimizations were performed in the $N$-alkyl chain, leading to AM-8553 (52, HTRF IC F0 $_{1}=1.1 \mathrm{nM}$, EdU SJSA-1 IC $\left.50=68 \mathrm{nM}\right)[119,122]$. This compound was able to inhibit tumor growth, but only promoted partial tumor regression in a SJSA-1 xenograft tumor model [123]. Therefore, further optimization was pursued. The co-crystal structure of 52 with MDM2 showed a shallow hydrophobic cleft near Phe19(p53) pocket that could be filled in order to enhance binding. Therefore, several derivatives were synthesized containing different $\mathrm{N}$-side chains [124], leading to the very potent sulfonamide piperidone 53 (HTRF IC $50=0.091 \mathrm{nM}$, EdU SJSA-1 IC $50=0.48 \mathrm{nM}$, Figure 14) [125]. However, the sulfonamides proved less metabolically stable than 52. Further optimizations led to compound 54 (HTRF IC ${ }_{50}=0.1 \mathrm{nM}$, EdU SJSA- $1 \mathrm{IC}_{50}=3 \mathrm{nM}$, Figure 13) and compound AMG232 (55, HTRF IC $50=0.6 \mathrm{nM}$, EdU SJSA-1 IC $\left.\mathrm{IC}_{50}=9.1 \mathrm{nM}\right)$ [124]. Nevertheless it is noteworthy to point out that even a simple $N$-group can give rise to potent derivatives (56, HTRF IC $50=9 \mathrm{nM}$, EdU SJSA-1 IC $50=0.38 \mu \mathrm{M}$, Figure 14) [126]. Compound 55 entered clinical trials in 2012. Although compound 54 was more active than 55 it offered poorer PK properties in in vivo studies.

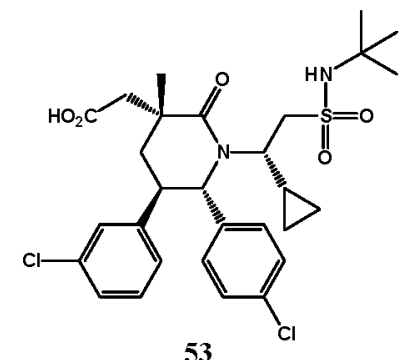

MDM2 $\mathrm{IC}_{50}=0.091 \mathrm{nM}$ SJSA-1 IC $_{50}=0.48 \mathrm{nM}$

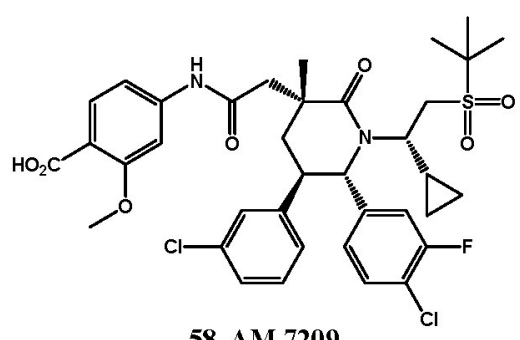

58, AM-7209

MDM2 $\mathrm{IC}_{50}<0.1 \mathrm{nM}$ SJSA-1 IC $50=1.6 \mathrm{nM}$

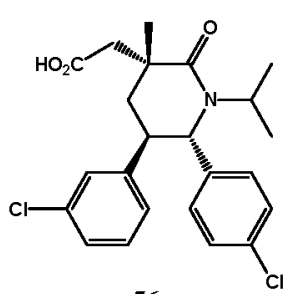

56

MDM2 $\mathrm{IC}_{50}=9 \mathrm{nM}$ SJSA-1 IC $I_{50}=380 \mathrm{nM}$

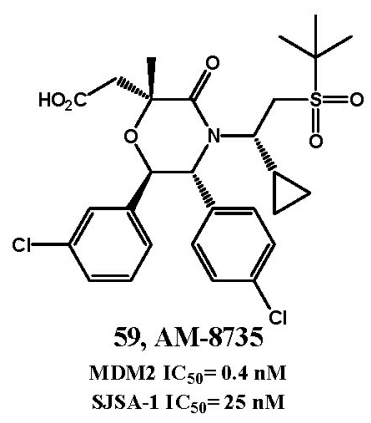

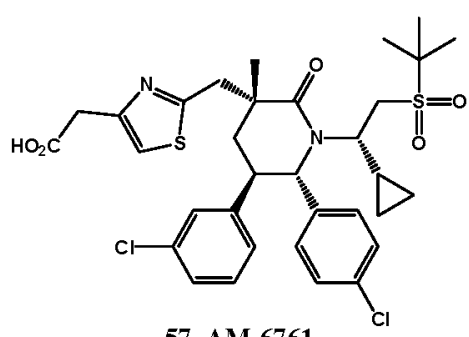

57, AM-6761

MDM2 $\mathrm{IC}_{50}=0.1 \mathrm{nM}$ SJSA-1 IC $50=16 \mathrm{nM}$

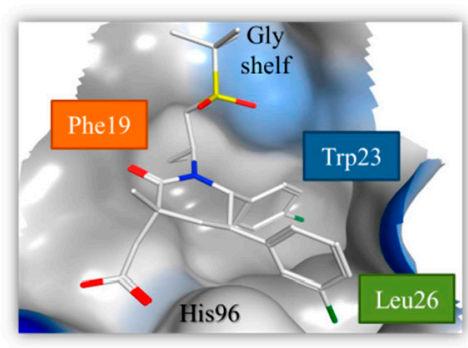

Figure 14. Piperidinone and morpholinone derivatives. Right lower quadrant: crystal structure of compound 54 bound to MDM2 (PDB 4OAS). MDM2 surface is colored in blue for hydrophilic areas and grey for hydrophobic areas. Compound $\mathbf{5 4}$ is depicted in stick model and is colored according to element type: white for carbon atoms, blue for the nitrogen atom, red for oxygen atoms, yellow for the sulfur atom, and green for chlorine atoms.

Binding of 55 with MDM2 was extrapolated from the co-crystal structure of 54 with MDM2 (Figure 14). As expected the three pivotal p53 amino acids Phe19, Trp23 and Leu26 are being mirrored by the isopropyl, C6 aryl group and C5 aryl group, respectively. Two substituents interact with His96: the $C 5$ aryl engages in a $\pi-\pi$ stacking, while the carboxylate function forms a hydrogen bond with its imidazole side chain. In addition, the sulfone group projects the terminal isopropyl into the glycine shelf region. Compound 55 was able to induce complete tumor regression in 10 out of 12 SJSA-1 xenograft mice $(60 \mathrm{mg} / \mathrm{Kg}$ administered orally once daily) [124,127]. Additional SAR studies were performed mainly by searching for new replacements for the carboxylate moiety that still allowed the interaction with His96 and possibly enhanced potency. This led to AM-6761 (57, HTRF IC I0 $=0.1 \mathrm{nM}$, EdU SJSA-1 IC $_{50}=16 \mathrm{nM}$ ) with potency similar to 55. Interestingly these 
two derivatives have different metabolic profile that can be of interest to explore. Compound $\mathbf{5 7}$ is primarily metabolized by oxidative pathways, while compound $\mathbf{5 5}$ is metabolized mainly by glucuronidation of the carboxylate moiety [128]. Further optimization led to AM-7209 (58, HTRF IC $50<0.1 \mathrm{nM}$, EdU SJSA-1 IC $50=1.6 \mathrm{nM}$ ) [129].

Alongside the synthesis of piperidones, Amgen continued to optimize morpholinone derivatives, leading to AM-8735 (59, HTRF IC $50=0.4 \mathrm{nM}$, EdU SJSA-1 IC $50=25 \mathrm{nM})$ [130]. In Table 2 and Figure 15 are described other p53-MDM2 interaction inhibitors with activity in the nanomolar range for MDM2 that have been reported throughout the years.

Apart from RG7112, MI77301, RG7388, and AMG232, another four small molecules have advanced into clinical trials, but no structural information is available: MK-8242, RO6839921, CGM097 and DS-3032b developed by Merck, Hoffmann-La Roche, Novartis International and Daiichi Sankyo, respectively [50].

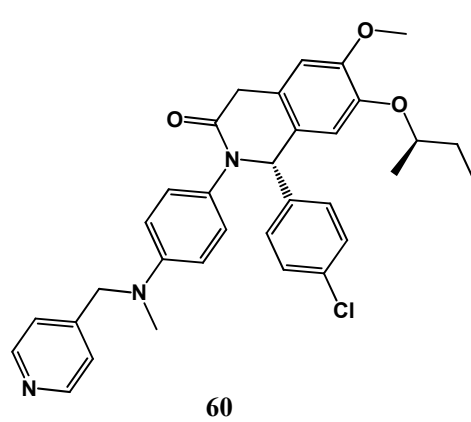

MDM2 $\mathrm{IC}_{50}=2.3 \mathrm{nM}$ SJSA-1 IC $_{50}=1.2 \mu \mathrm{M}$
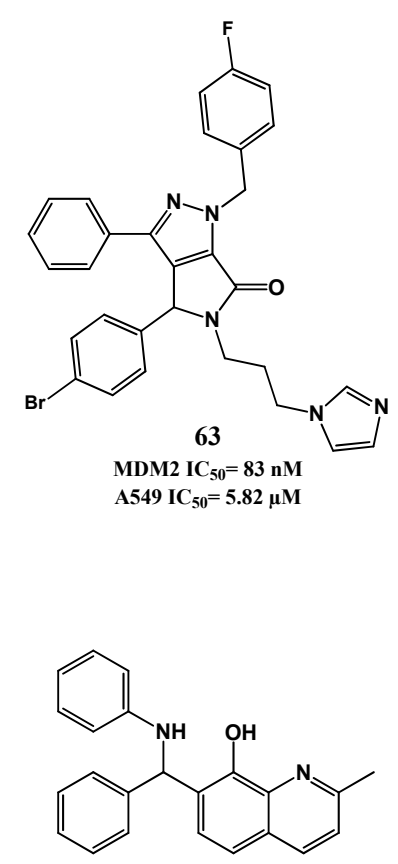

66

MDM2 Ki= $0.12 \mu M$<smiles>CC(C)Cc1cc(-c2cc(-c3ccc(CCC(=O)O)cc3CC(C)C)ccc2-c2ccc(Cc3ccc4ccccc4c3)cc2CC(C)C)ccc1OCC(=O)O</smiles>

MDM2 $\mathrm{IC}_{50}=0.18 \mu \mathrm{M}$

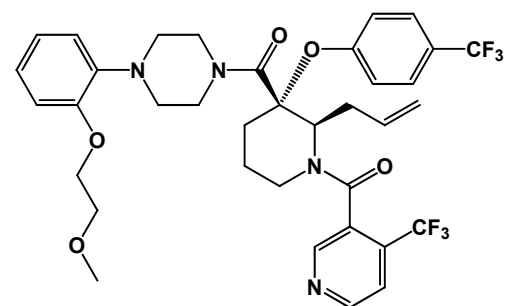

64

MDM2 $\mathrm{IC}_{50}=41 \mathrm{nM}$

SJSA-1 IC S0 $_{50}=1 \mu \mathrm{M}$<smiles>N#Cc1c(N)nc(SCC(=O)c2ccc(O)c(O)c2)c(C#N)c1-c1ccc(O)cc1</smiles>

67

MDM2 Ki= $0.11 \mu \mathrm{M}$<smiles>CC(NC1=C(C(=O)c2ccccc2)C(c2ccc(Br)cc2)N(Cc2cccnc2)C1=O)c1ccccc1</smiles>

MDM2 $\mathrm{IC}_{50}=90 \mathrm{nM}$<smiles>COc1ccc(/C=C2\C(=O)Nc3ccccc32)c(OC)c1</smiles>

65

MDM2 $\mathrm{IC}_{50}=93 \mathrm{nM}$ $\mathrm{HCT116}^{+++} \mathrm{IC}_{50}=13.42 \mu \mathrm{M}$

68

MDM2 IC $_{50}=2 \mathrm{nM}$ SJSA-1 IC $_{50}=0.5 \mu \mathrm{M}$

Figure 15. p53-MDM2 interaction inhibitors. 
Table 2. Other chemical families described for p53-MDM2 interaction inhibitors.

\begin{tabular}{cccc}
\hline Chemical Family & Compound & MDM2 $\left(\mathbf{I C}_{\mathbf{5 0}}\right.$ or Ki) & Cell-Based Assay $\left(\mathbf{I C}_{\mathbf{5 0}}\right)$ \\
\hline Dihydroisoquinolinones [131] & $\mathbf{6 0}$ & $\mathrm{IC}_{50}=2.3 \mathrm{nM}^{\mathrm{a}}$ & $1.2 \mu \mathrm{M}(\mathrm{SJSA}-1)$ \\
Terphenyl derivatives [132,133] & $\mathbf{6 1}$ & $\mathrm{Ki}=180 \mathrm{nM}^{\mathrm{b}}$ & $\mathrm{ND}^{\mathrm{f}}$ \\
Pyrrolidones [134,135] & $\mathbf{6 2}$ & $\mathrm{IC}_{50}=90 \mathrm{nM}^{\mathrm{c}}$ & $\mathrm{ND}^{\mathrm{f}}$ \\
Pyrrolo[3,4-c]pyrazoles [136,137] & $\mathbf{6 3}$ & $\mathrm{IC}_{50}=83 \mathrm{nM}^{\mathrm{c}}$ & $5.8 \mu \mathrm{M}(\mathrm{A} 549)^{\mathrm{d}}$ \\
Piperidines [138-140] & $\mathbf{6 4}$ & $\mathrm{IC}_{50}=41 \mathrm{nM}^{\mathrm{c}}$ & $1.0 \mu \mathrm{M}(\mathrm{SJSA}-1)^{\mathrm{d}}$ \\
3-benzylideneindolin-2-ones [141] & $\mathbf{6 5}$ & $\mathrm{Ki}=93 \mathrm{nM}^{\mathrm{c}}$ & $13.4 \mu \mathrm{M}\left(\mathrm{HCT} 116 \mathrm{p}^{(+/+)}\right)^{\mathrm{d}}$ \\
8-hydroxyquinoline [142] & $\mathrm{NSC66811(66)}$ & $\mathrm{Ki}=120 \mathrm{nM}^{\mathrm{c}}$ & $\mathrm{ND}^{\mathrm{f}}$ \\
Pyridine derivative [143] & $\mathbf{6 7}$ & $\mathrm{Ki}=110 \mathrm{nM}^{\mathrm{c}}$ & $\mathrm{ND}^{\mathrm{f}}$ \\
Imidazole [144] & $\mathbf{6 8}$ & $\mathrm{IC}_{50}=2 \mathrm{nM}^{\mathrm{a}}$ & $0.5 \mu \mathrm{M}(\mathrm{SJSA}-1)^{\mathrm{e}}$ \\
\hline
\end{tabular}

${ }^{a}$ TR-FRET; ${ }^{b}$ ELISA; ${ }^{c}$ FP; ${ }^{d}$ MTT; ${ }^{\mathrm{e}}$ YO-PRO ${ }^{\circledR}$-1iodide staining; ${ }^{f}$ not determined.

\subsection{MDMX and Dual MDM2/MDMX Inhibitors}

Although MDM2 is the foremost negative regulator of p53, MDMX has been recognized more recently as a critical discrete p53 modulator, and in fact its overexpression is observed in several cancers $[145,146]$. MDMX is structurally related to MDM2, but lacks its p53 ubiquitin-mediated degradation signal. However it is able to control p53 activity mostly by inhibiting the p53 transcription function. In addition, MDMX protein levels are regulated by MDM2 ubiquitin-mediated degradation [147]. Since inhibiting p53-MDM2 interaction increase MDM2 levels by autoregulatory feedback loop, and therefore can facilitate MDMX degradation, the problem of MDMX presence could be lessened when targeting this interaction. However, although reduced MDMX levels are observed in many cancers after treatment with nutlin-3a, the effectiveness of the inhibitor can still be compromised, especially in tumors overexpressing MDMX [148].

The first small molecule inhibitor of MDMX (SJ-172550, 69, Figure 16) was only reported in 2010. This compound was found to bind reversibly to MDMX in the p53 binding pocket, and showed cytotoxicity in MDMX-amplified retinoblastoma cell line Weri1 [149]. Further investigation revealed that compound 69, through reversible covalent binding, seemingly locks MDMX into a conformation that is unable to bind p53. This complex mechanism of action was revealed to be dependent on several factors, limiting this compound as a feasible lead compound [150].<smiles>COC(=O)COc1ccc(C=C2C(=O)N(c3ccccc3)N=C2C)cc1Cl</smiles>

69, SJ-172550<smiles>Cc1c2ccccc2c(CSC(=N)N)c2ccccc12</smiles>

70, XI-011

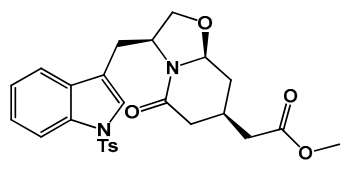

72, OXAZ-1
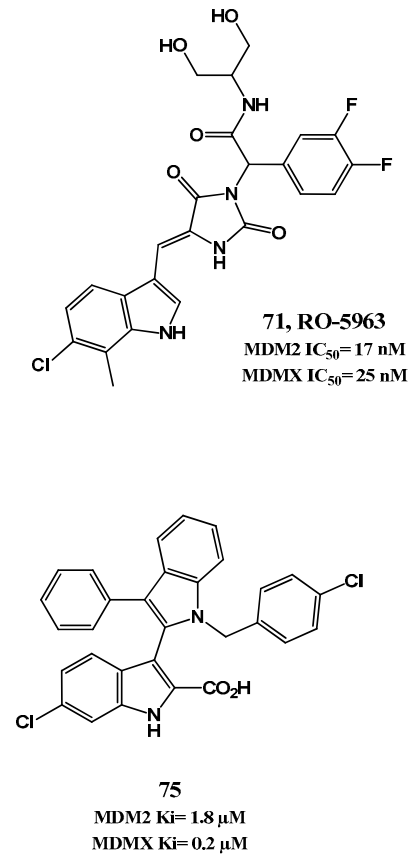

75

MDM2 Ki= $1.8 \mu \mathrm{M}$ MDMX Ki $=0.2 \mu \mathrm{M}$

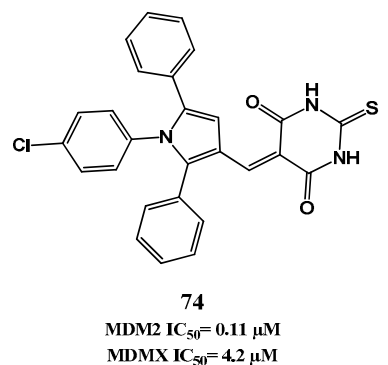

Figure 16. MDMX and dual MDM2/MDMX inhibitors. 
Compounds XI-006 (NSC207895) and XI-011 (NSC146109, 70) were identified in a HTS assay as activators of p53-dependent transcription [151]. The mechanism of action of these compounds was unveiled in 2011 to involve inhibition of MDMX expression, by repressing MDMX promoter and subsequent down-regulation of its mRNA [28,152]. Recently it was also suggested that XI-011 was capable of disrupting the p53-MDMX interaction [153].

Although initially some reports demonstrated the beneficial aspect of inhibiting MDMX alone, specially due to its lower toxicity to normal tissues [148], it is now recognized that a full p53 activation outcome is favored and more likely to be achieved with dual inhibition of MDM2 and MDMX. In fact, compounds possessing an imidazo-indole scaffold act as dual inhibitors (e.g., WK298, 42, MDM2 FP $\mathrm{IC}_{50}=0.19 \mu \mathrm{M} ;$ MDMX FP IC ${ }_{50}=19.7 \mu \mathrm{M}$, Figure 11). The co-crystal structure of WK298 with MDMX confirmed that the main aspects that need to be addressed for an adequate inhibition of both proteins lies in the three subpockets Phe19 ${ }_{(p 53)}, \operatorname{Trp} 23_{(p 53)}$ and Leu26 ${ }_{(p 53)}$. The difficulty of dual inhibition seems to be attributed mainly to Leu26(p53) pocket, which is quite different in the two proteins, and may be the reason for a much weaker binding observed for most of the known MDM2 inhibitors. From this observation it can be assumed that the common feature of possessing a chlorophenyl group, although ideal for MDM2, is not optimal for mimicking p53 Leu26 interaction with MDMX [114].

More recently, indolyl-hydantoin derivatives were reported to potently block p53 binding with both MDM2 and MDMX. Specifically, compound RO-5963 (71, MDM2 TR-FRET IC $50=17 \mathrm{nM}$; MDMX TR-FRET $\mathrm{IC}_{50}=25 \mathrm{nM}$ ) showed p53-MDM2 inhibitory activity similar to that of nutlin-3a and approximately 400-fold better p53-MDMX inhibitory activity than nutlin-3a [154]. Other small molecules (Figure 16) have been identified as dual inhibitors in the last years, including tryptophanol-derived oxazolopiperidone lactam 72 [155], pyrrolidones (73, MDM2 FP IC I0 $=0.26 \mu \mathrm{M}$; MDMX FP IC I0 $\left._{2}=2.68 \mu \mathrm{M}\right)$ [134], triaryl-pyrroles (74, MDM2 FP IC ${ }_{50}=0.11 \mu \mathrm{M}$; MDMX FP IC $\left.{ }_{50}=4.2 \mu \mathrm{M}\right)[156]$, and 2, $3^{\prime}$-bis $\left(1^{\prime} \mathrm{H}\right.$-indoles $)$ (75, MDM2 FP Ki $=1.8 \mu \mathrm{M}$; MDMX FP Ki $=0.2 \mu \mathrm{M})$ [157].

\section{3. p53 Reactivators: wt p53 and Mut p53 Targeting Small Molecules}

Apart from inhibition of p53-MDMs interactions, other approaches have been used in order to reactivate wild-type p53 including targeting MDM2 E3 ligase, sirtuins, the calcium-binding protein $\mathrm{S} 100 \mathrm{~B}$, etc. In addition, p53 function perturbations are also observed in cancers as a result of point mutations to the TP53 gene, representing the most frequent mutated gene observed in human cancers. Although in some cases such events can lead to loss of p53 protein expression, as a result of frameshift or nonsense mutations, more frequently it leads to a single amino acid substitution in the protein (missense mutations). These replacements take place more frequently within the DNA binding domain leading to loss or attenuation of wild-type p53 function. p53 mutants can generically be categorized into two groups: contact mutants, in which the amino acid replacement affects p53's ability to bind to DNA without significantly affecting its conformation; and conformational mutants, in which the substitution promotes a disruption of the normal p53 tertiary structure. However, the signaling outcome cannot be oversimplified in two possible outcomes, since different mutations can lead to different degrees of inhibition/loss of p53 function, as well as to the acquisition of increased function. This gain of function can further promote tumorigenesis, potentially leading to a more aggressive cancer profile. Gain of function by mutant $\mathrm{p} 53$ can be a consequence of the activation of other signaling pathways, through interaction with other proteins, such as the p53 family members p63 and p73, and indirectly affecting gene expression. The intricacy of this mutant p53 signaling disturbance effect is further amplified by the fact that different expression of its targets can be met in different tissues, potentially generating the variety of cancer phenotypes observed, even for the same point mutation [158,159].

A variety of small-molecule therapy strategies can be devised when dealing with mutant p53, such as: (i) reactivation of wild-type p53 function; (ii) interference with the interaction between mutant p53 and other proteins; (iii) promotion of mutant p53 degradation; and (iv) downstream interference in the mutant p53 signaling pathways. 
To date, there are some small molecules reported to target mut p53. For most of them, the mechanism of action is still not fully understood. Moreover, some of these molecules show p53-independent activity and cytotoxicity in cancers with wild-type p53 [21,158-160]. For example, Reactivation of p53 and Induction of Tumor Cell Apoptosis (RITA, 76, Figure 17) was identified to suppress selectively HCT116 cell line expressing wild-type p53 over the p53 null counterpart cell line. It was proposed that RITA binds to the p53 $\mathrm{N}$-terminal domain, inducing a conformational change that prevents its binding to MDM2, thus restoring p53-transcriptional activity [161,162]. Interestingly, more recently RITA's mechanism of action was extended to cell lines presenting mutated p53. Presumably the binding to mutated p53 might affect the core domain folding in a way that potentially restore its DNA binding ability [163]. This dual targeting increases the application scope of RITA turning it into a very promising lead compound to rescue p53 regardless of the nature of its inactivation [164]. In addition, RITA can promote down-regulation of MDMX selectively in wild-type cancer cells through a pathway independent of MDM2 [165]. Novel analogues slightly more active and selective have been already synthesized [166,167].

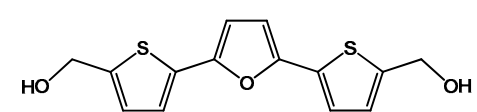

76, RITA

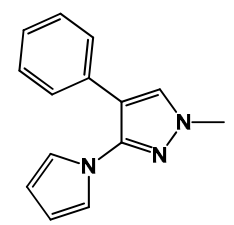

77, PK7088

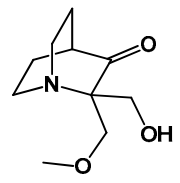

78, PRIMA-1 ${ }^{\text {MET }}$<smiles>CC1=C2C(O)=C(C)c3c(C)cc(O)c(C=O)c3OC2C(O)OC1=O</smiles>

79, Stictic acid<smiles>COc1ccc(/C=C/c2nc(NCCCN(C)C)c3ccccc3n2)cc1</smiles>

80, CP-31398<smiles>C=Cc1nc2ccccc2c(=O)[nH]1</smiles>

81, STIMA-1<smiles>CCC(=O)OCN1C(=O)C=CC1=O</smiles>

82, MIRA-1<smiles>CN(C)CCCNc1nc(CN2CCN(C(c3ccc(Cl)cc3)c3ccc(Cl)cc3)CC2)nc2ccccc12</smiles>

83, SCH529074<smiles>C/C(=N\NC(=S)N1CCC1)c1ccccn1</smiles>

84, NSC319726

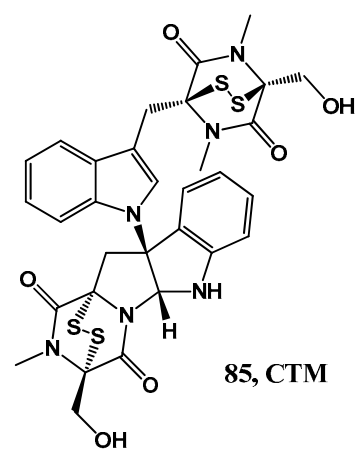<smiles>C[C@]12OCC(Cc3c[nH]c4ccccc34)N1C(=O)c1ccccc12</smiles>

86, SLMP53-1<smiles>O=C(CCCCCCC(=O)Nc1ccccc1)NO</smiles>

87, SAHA<smiles>O=C(CSC1=NCCS1)c1ccc(O)c(O)c1</smiles>

88, RETRA

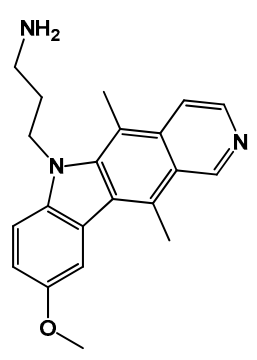

89, $\operatorname{NSC1} 176327$

Figure 17. Compounds targeting mutant p53. 
Several small molecules were reported to restore wt p53 function. Specifically, PhiKan083 [168], PhiKan5196 [169], and PK7088 (77) [170] are small molecules that target the Y220C p53 mutation, a mutation that creates a druggable surface crevice that destabilizes the protein.

PRIMA-1, and PRIMAMET (APR-246, 78) [171,172], target the R175H and R273H p53 mutations. These molecules are converted into compounds capable of forming adducts with mutant p53 cysteine residues. APR-246 is currently in clinical trials [173]. Another small molecule that acts on mutated p53 is stictic acid (79) that in human osteosarcoma cells, exhibits dose-dependent reactivation of p21 expression for mutant R175H more strongly than does PRIMA-1 [174].

CP-31398 (80), a styrylquinazoline, emerged from a high throughput screen for compounds that restore a wild-type-associated epitope (monoclonal antibody 1620) on the DNA-binding domain of the p53 protein. CP-31398 (80) stabilizes exogenous p53 in p53 mutant (mutant p53 V173A and R249S), wild-type, p53-null human cells, and in MDM2-null p53-/- mouse embryonic fibroblasts $[175,176]$.

STIMA-1 (a compound with some structural similarities to CP-31398) and MIRA-1, identified in a cellular screening, are also reactivators of mutant p53. Both STIMA-1 (81) [177] and MIRA-1 (82) [178], probably restore the wt p53 function by reacting with thiols and amino groups in p53. MIRA-1 reactivates mutant p53 $\mathrm{R} 175 \mathrm{H}$ and $\mathrm{R} 273 \mathrm{H}$, but it was recently reported to have off-target effects [160].

SCH529074 (83) was identified using a screen based on a p53 DNA binding assay. SCH529074 (83) restores DNA binding activity to two mutant forms of p53, the contact point mutant $\mathrm{R} 273 \mathrm{H}$ and the structural mutant R249S. Moreover, it binds to p53 core domain and it is believed to act as a chaperone, not binding covalently to p53. It also inhibits MDM2-mediated ubiquitination [179]. NSC319726 (ZMC1, 84) is a reactivator of $\mathrm{R} 175 \mathrm{H}$ mutant $\mathrm{p} 53$ and functions as zinc metallochaperone, providing an optimal concentration of zinc to p53, promoting proper folding of p53-R175H [180,181].

The natural compound, chemotin (CTM, 85), was identified to act as a mut p53 reactivator using a cell-based, high-throughput small-molecule screen. CTM inhibits growth of cancer cells harboring mutant p53 $\mathrm{R} 175 \mathrm{H}$ in vitro and in vivo, binds to $\mathrm{Hsp} 40$ and increases the binding capacity of Hsp40 to the p53 R175H mutant protein, causing a potential conformational change to a wild-type-like p53 [182]. More recently, the enantiopure tryptophanol-derived oxazoloisoindolinone (SLMP-53-1, 86) was identified as a novel reactivator of wild-type (wt) and mut p53. SLMP-53-1 enhanced p53 transcriptional activity, restored wt-like DNA binding ability to mut p53R280K, and showed promising p53-dependent synergistic effects with conventional chemotherapeutics. Moreover, in xenograft mice models, it inhibited the growth of wt/mut p53-expressing tumors, but not of p53-null tumors, without apparent toxicity [183].

Vorinostat (SAHA, 87) was described as a histone deacetylase inhibitor and can destabilize the complex formed between HSP90 and mut p53. This complex inhibits E3 ubiquitin ligases MDM2 and CHIP, causing mut p53 stabilization. Moreover, the $\mathrm{IC}_{50}$ values were profoundly lower in mut p53 cancer cells (T47D IC $50=1.7 \mu \mathrm{M} ;$ MDA231 IC $50=1.1 \mu \mathrm{M}$; ES2 IC $50=1.9 \mu \mathrm{M}$ ) over wt p53 cancer cells

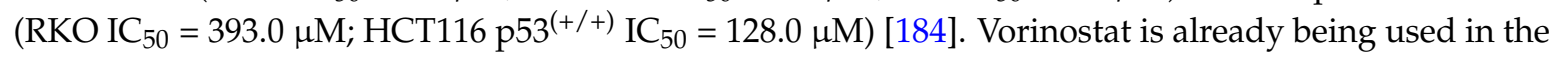
clinic for treatment of cutaneous T cell lymphoma [173].

Other small molecules that act on mutated p53 are RETRA (88) [185] and NSC176327 (89) (a derivative of ellipticine) [186] which promote the release of p73 protein from the blocking complex with mutant p53. In particular, RETRA is active against tumor cells expressing a variety of p53 mutants (His-273, Trp-248, Glu-266, Lys-280), while not affecting normal cells [185].

\section{Concluding Remarks}

Due to the unquestionable contribution of p53 to the preservation of genomic integrity, it is not surprising that tumor pathogenesis and development involves some sort of p53 impairment. Hence, restoring p53 function in cancer cells represents a valuable anticancer approach. Several strategies are being developed and in particular targeting p53-MDM2 interaction has emerged as a promising approach, when dealing with cancers that retain wild-type p53 function. In particular, 
seven p53-MDM2 interaction inhibitors have entered clinical trials. However, it was recently shown by Aziz et al. that non-genotoxic p53 activation by the MDM2 inhibitor, nutlin-3a, can lead to the acquisition of somatic mutations in p53 [59]. If these studies are confirmed with other MDM2 inhibitors, they will have implications for the potential clinical use of MDM2 antagonists.

More recently, the strategies to target p53 involve the dual inhibition of the p53-MDM2 and p53-MDMX interactions to effectively activate wild-type p53. In the case of more aggressive cancers where p53 is mutated, the strategy involves the development of small molecules that target mut p53.

As one of the main problems when dealing with any chemotherapeutic agent is its toxicity to normal cells, it is important to find new drugs that can distinguish cancer cells from normal cells. Non-genotoxic strategies that focus on reactivating p53 can represent a step further in this direction, due to the fact that the outcome of p53 activation relies, among other factors, in the intracellular environment that per se is different in cancer and normal cells. In the case of tumors with mutated p53, p53 status represents an inherent difference between these two types of cells and therefore p53-based cyclotherapy can be a very useful strategy. In this approach, first it is given a pretreatment with a low dose of wild-type p53 activating molecule that can trigger a transient cell cycle arrest in normal cells, without affecting cancer cells. Then, by adding a conventional anticancer agent that targets $\mathrm{S}$ and $\mathrm{M}$ phase, cancer cells will selectively be triggered into an apoptotic outcome [187].

Acknowledgments: We thank FCT (Fundação para a Ciência e a Tecnologia, Portugal) for the financial support through iMed.ULisboa (UID/DTP/04138/2013), and fellowship SFRH/BD/69258/2010 (Carlos J. A. Ribeiro). Maria M. M. Santos would like to acknowledge FCT, "Programa Operacional Potencial Humano" and the European Social Fund for the IF Program (IF/00732/2013).

Conflicts of Interest: The authors declare no conflict of interest. The founding sponsors had no role in the design of the study; in the collection, analyses, or interpretation of data; in the writing of the manuscript, and in the decision to publish the results.

\section{References}

1. Levine, A.J.; Oren, M. The first 30 years of p53: Growing ever more complex. Nat. Rev. Cancer 2009, 9, 749-758. [CrossRef] [PubMed]

2. Bieging, K.T.; Mello, S.S.; Attardi, L.D. Unravelling mechanisms of p53-mediated tumour suppression. Nat. Rev. Cancer 2014, 14, 359-370. [CrossRef] [PubMed]

3. Brown, C.J.; Lain, S.; Verma, C.S.; Fersht, A.R.; Lane, D.P. Awakening guardian angels: Drugging the p53 pathway. Nat. Rev. Cancer 2009, 9, 862-873. [CrossRef] [PubMed]

4. Vousden, K.H.; Lane, D.P. P53 in health and disease. Nat. Rev. Mol. Cell Biol. 2007, 8, 275-283. [CrossRef] [PubMed]

5. Meek, D.W. Tumour suppression by p53: A role for the DNA damage response? Nat. Rev. Cancer 2009, 9, 714-723. [CrossRef] [PubMed]

6. Brady, C.A.; Attardi, L.D. p53 at a glance. J. Cell Sci. 2010, 123, 2527-2532. [CrossRef] [PubMed]

7. Vousden, K.H.; Prives, C. Blinded by the light: The growing complexity of p53. Cell 2009, 137, 413-431. [CrossRef] [PubMed]

8. Kastan, M.B. Wild-type p53: Tumors can't stand it. Cell 2007, 128, 837-840. [CrossRef] [PubMed]

9. Feldser, D.M.; Kostova, K.K.; Winslow, M.M.; Taylor, S.E.; Cashman, C.; Whittaker, C.A.; Sanchez-Rivera, F.J.; Resnick, R.; Bronson, R.; Hemann, M.T.; et al. Stage-specific sensitivity to 553 restoration during lung cancer progression. Nature 2010, 468, 572-575. [CrossRef] [PubMed]

10. Christophorou, M.A.; Martin-Zanca, D.; Soucek, L.; Lawlor, E.R.; Brown-Swigart, L.; Verschuren, E.W.; Evan, G.I. Temporal dissection of p53 function in vitro and in vivo. Nat. Genet. 2005, 37, 718-726. [CrossRef] [PubMed]

11. Shangary, S.; Wang, S. Small-molecule inhibitors of the MDM2-p53 protein-protein interaction to reactivate p53 function: A novel approach for cancer therapy. Annu. Rev. Pharmacol. Toxicol. 2009, 49, $223-241$. [CrossRef] [PubMed]

12. Cheok, C.F.; Verma, C.S.; Baselga, J.; Lane, D.P. Translating p53 into the clinic. Nat. Rev. Clin. Oncol. 2011, 8, 25-37. [CrossRef] [PubMed] 
13. Selivanova, G. Therapeutic targeting of p53 by small molecules. Semin. Cancer Biol. 2010, 20, 46-56. [CrossRef] [PubMed]

14. Wang, Z.; Sun, Y. Targeting p53 for novel anticancer therapy. Transl. Oncol. 2010, 3, 1-12. [CrossRef] [PubMed]

15. Athar, M.; Elmets, C.A.; Kopelovich, L. Pharmacological activation of p53 in cancer cells. Curr. Pharm. Des. 2011, 17, 631-639. [CrossRef] [PubMed]

16. Kim, S.-H.; Dass, C.R. p53-targeted cancer pharmacotherapy: Move towards small molecule compounds. J. Pharm. Pharmacol. 2011, 63, 603-610. [CrossRef] [PubMed]

17. Essmann, F.; Schulze-Osthoff, K. Translational approaches targeting the p53 pathway for anti-cancer therapy. Br. J. Pharmacol. 2012, 165, 328-344. [CrossRef] [PubMed]

18. Stegh, A.H. Targeting the p53 signaling pathway in cancer therapy-The promises, challenges and perils. Expert Opin. Ther. Targets 2012, 16, 67-83. [CrossRef] [PubMed]

19. Golubovskaya, V.M.; Cance, W.G. Targeting the p53 pathway. Surg. Oncol. Clin. N. Am. 2013, 22, 747-764. [CrossRef] [PubMed]

20. Duffy, M.J.; Synnott, N.C.; McGowan, P.M.; Crown, J.; O'Connor, D.; Gallagher, W.M. p53 as a target for the treatment of cancer. Cancer Treat. Rev. 2014, 40, 1153-1160. [CrossRef] [PubMed]

21. Hoe, K.K.; Verma, C.S.; Lane, D.P. Drugging the p53 pathway: Understanding the route to clinical efficacy. Nat. Rev. Drug Discov. 2014, 13, 217-236. [CrossRef] [PubMed]

22. Hong, B.; van den Heuvel, A.P.J.; Prabhu, V.V.; Zhang, S.; El-Deiry, W.S. Targeting tumor suppressor p53 for cancer therapy: Strategies, challenges and opportunities. Curr. Drug Targets 2014, 15, 80-89. [CrossRef] [PubMed]

23. Selivanova, G. Wild type p53 reactivation: From lab bench to clinic. FEBS Lett. 2014, 588, $2628-2638$. [CrossRef] [PubMed]

24. Yu, X.; Narayanan, S.; Vazquez, A.; Carpizo, D.R. Small molecule compounds targeting the p53 pathway: Are we finally making progress? Apoptosis 2014, 19, 1055-1068. [CrossRef] [PubMed]

25. Zawacka-Pankau, J.; Selivanova, G. Pharmacological reactivation of p53 as a strategy to treat cancer. J. Intern. Med. 2015, 277, 248-259. [CrossRef] [PubMed]

26. Tazawa, H.; Kagawa, S.; Fujiwara, T. Advances in adenovirus-mediated p53 cancer gene therapy. Expert Opin. Biol. Ther. 2013, 13, 1569-1583. [CrossRef] [PubMed]

27. Chene, P. Inhibition of the p53-MDM2 interaction: Targeting a protein-protein interface. Mol. Cancer Res. 2004, 2, 20-28. [PubMed]

28. Buolamwini, J.K.; Addo, J.; Kamath, S.; Patil, S.; Mason, D.; Ores, M. Small molecule antagonists of the MDM2 oncoprotein as anticancer agents. Curr. Cancer Drug Targets 2005, 5, 57-68. [CrossRef] [PubMed]

29. Fotouhi, N.; Graves, B. Small molecule inhibitors of p53/MDM2 interaction. Curr. Top. Med. Chem. 2005, 5, 159-165. [CrossRef] [PubMed]

30. Deng, J.X.; Dayam, R.; Neamati, N. Patented small molecule inhibitors of p53-MDM2 interaction. Expert Opin. Ther. Patents 2006, 16, 165-188. [CrossRef] [PubMed]

31. Fischer, P.M. Peptide, peptidomimetic, and small-molecule antagonists of the p53-HDM2 protein-protein interaction. Int. J. Pept. Res. Ther. 2006, 12, 3-19. [CrossRef] [PubMed]

32. Dudkina, A.S.; Lindsley, C.W. Small molecule protein-protein inhibitors for the p53-MDM2 interaction. Curr. Top. Med. Chem. 2007, 7, 952-960. [CrossRef] [PubMed]

33. Hardcastle, I.R. Inhibitors of the MDM2-p53 interaction as anticancer drugs. Drugs Future 2007, 32, 883-896. [CrossRef]

34. Vassilev, L.T. MDM2 inhibitors for cancer therapy. Trends Mol. Med. 2007, 13, 23-31. [CrossRef] [PubMed]

35. Hu, C.-Q.; Hu, Y.-Z. Small molecule inhibitors of the p53-MDM2. Curr. Med. Chem. 2008, 15, 1720-1730. [CrossRef] [PubMed]

36. Patel, S.; Player, M.R. Small-molecule inhibitors of the p53-HDM2 interaction for the treatment of cancer. Expert Opin. Investig. Drugs 2008, 17, 1865-1882. [CrossRef] [PubMed]

37. Shangary, S.; Wang, S. Targeting the MDM2-p53 interaction for cancer therapy. Clin. Cancer Res. 2008, 14, 5318-5324. [CrossRef] [PubMed]

38. Dickens, M.P.; Fitzgerald, R.; Fischer, P.M. Small-molecule inhibitors of MDM2 as new anticancer therapeutics. Semin. Cancer Biol. 2010, 20, 10-18. [CrossRef] [PubMed] 
39. Weber, L. Patented inhibitors of p53-MDM2 interaction (2006-2008). Expert Opin. Ther. Patents 2010, 20, 179-191. [CrossRef] [PubMed]

40. Millard, M.; Pathania, D.; Grande, F.; Xu, S.; Neamati, N. Small-molecule inhibitors of p53-MDM2 interaction: The 2006-2010 update. Curr. Pharm. Des. 2011, 17, 536-559. [CrossRef] [PubMed]

41. Shen, H.; Maki, C.G. Pharmacologic activation of p53 by small-molecule MDM2 antagonists. Curr. Pharm. Des. 2011, 17, 560-568. [CrossRef] [PubMed]

42. Kamal, A.; Mohammed, A.A.; Shaik, T.B. p53-MDM2 inhibitors: Patent review (2009-2010). Expert Opin. Ther. Patents 2012, 22, 95-105. [CrossRef] [PubMed]

43. Khoury, K.; Doemling, A. p53 MDM2 inhibitors. Curr. Pharm. Des. 2012, 18, 4668-4678. [CrossRef] [PubMed]

44. Carry, J.-C.; Garcia-Echeverria, C. Inhibitors of the p53/HDM2 protein-protein interaction-path to the clinic. Bioorg. Med. Chem. Lett. 2013, 23, 2480-2485. [CrossRef] [PubMed]

45. Nag, S.; Zhang, X.; Srivenugopal, K.S.; Wang, M.H.; Wang, W.; Zhang, R. Targeting MDM2-p53 interaction for cancer therapy: Are we there yet? Curr. Med. Chem. 2014, 21, 553-574. [CrossRef] [PubMed]

46. Zhao, Y.; Aguilar, A.; Bernard, D.; Wang, S. Small-molecule inhibitors of the MDM2-p53 protein-protein interaction (MDM2 inhibitors) in clinical trials for cancer treatment. J. Med. Chem. 2015, 58, 1038-1052. [CrossRef] [PubMed]

47. Wu, X.W.; Bayle, J.H.; Olson, D.; Levine, A.J. The p53 MDM-2 autoregulatory feedback loop. Genes Dev. 1993, 7, 1126-1132. [CrossRef] [PubMed]

48. Zhao, Y.; Yu, H.; Hu, W. The regulation of MDM2 oncogene and its impact on human cancers. Acta Biochim. Biophys. Sin. 2014, 46, 180-189. [CrossRef] [PubMed]

49. Kussie, P.H.; Gorina, S.; Marechal, V.; Elenbaas, B.; Moreau, J.; Levine, A.J.; Pavletich, N.P. Structure of the MDM2 oncoprotein bound to the p53 tumor suppressor transactivation domain. Science 1996, 274, 948-953. [CrossRef] [PubMed]

50. ClinicalTrials.gov. Available online: http://clinicaltrials.gov/ (accessed on 5 May 2016).

51. Vassilev, L.T.; Vu, B.T.; Graves, B.; Carvajal, D.; Podlaski, F.; Filipovic, Z.; Kong, N.; Kammlott, U.; Lukacs, C.; Klein, C.; et al. In vivo activation of the p53 pathway by small-molecule antagonists of MDM2. Science 2004, 303, 844-848. [CrossRef] [PubMed]

52. Popowicz, G.M.; Doemling, A.; Holak, T.A. The structure-based design of MDM2/MDMX-p53 inhibitors gets serious. Angew. Chem. Int. Ed. 2011, 50, 2680-2688. [CrossRef] [PubMed]

53. Stuhmer, T.; Chatterjee, M.; Hildebrandt, M.; Herrmann, P.; Gollasch, H.; Gerecke, C.; Theurich, S.; Cigliano, L.; Manz, R.A.; Daniel, P.T.; et al. Nongenotoxic activation of the p53 pathway as a therapeutic strategy for multiple myeloma. Blood 2005, 106, 3609-3617. [CrossRef] [PubMed]

54. Tovar, C.; Rosinski, J.; Filipovic, Z.; Higgins, B.; Kolinsky, K.; Hilton, H.; Zhao, X.L.; Vu, B.T.; Qing, W.G.; Packman, K.; et al. Small-molecule MDM2 antagonists reveal aberrant p53 signaling in cancer: Implications for therapy. Proc. Natl. Acad. Sci. USA 2006, 103, 1888-1893. [CrossRef] [PubMed]

55. Drakos, E.; Thomaides, A.; Medeiros, L.J.; Li, J.; Leventaki, V.; Konopleva, M.; Andreeff, M.; Rassidakis, G.Z. Inhibition of p53-murine double minute 2 interaction by nutlin-3a stabilizes p53 and induces cell cycle arrest and apoptosis in hodgkin lymphoma. Clin. Cancer Res. 2007, 13, 3380-3387. [CrossRef] [PubMed]

56. Gu, L.; Zhu, N.; Findley, H.W.; Zhou, M. MDM2 antagonist nutlin-3 is a potent inducer of apoptosis in pediatric acute lymphoblastic leukemia cells with wild-type p53 and overexpression of MDM2. Leukemia 2008, 22, 730-739. [CrossRef] [PubMed]

57. Zheng, T.; Wang, J.; Song, X.; Meng, X.; Pan, S.; Jiang, H.; Liu, L. Nutlin-3 cooperates with doxorubicin to induce apoptosis of human hepatocellular carcinoma cells through p53 or p73 signaling pathways. J. Cancer Res. Clin. Oncol. 2010, 136, 1597-1604. [CrossRef] [PubMed]

58. Ohnstad, H.O.; Paulsen, E.B.; Noordhuis, P.; Berg, M.; Lothe, R.A.; Vassilev, L.T.; Myklebost, O. MDM2 antagonist nutlin-3a potentiates antitumour activity of cytotoxic drugs in sarcoma cell lines. BMC Cancer 2011, 11. [CrossRef] [PubMed]

59. Vu, B.; Wovkulich, P.; Pizzolato, G.; Lovey, A.; Ding, Q.J.; Jiang, N.; Liu, J.J.; Zhao, C.L.; Glenn, K.; Wen, Y.; et al. Discovery of rg7112: A small-molecule MDM2 inhibitor in clinical development. ACS Med. Chem. Lett. 2013, 4, 466-469. [CrossRef] [PubMed] 
60. Ray-Coquard, I.; Blay, J.-Y.; Italiano, A.; le Cesne, A.; Penel, N.; Zhi, J.; Heil, F.; Rueger, R.; Graves, B.; Ding, M.; et al. Effect of the MDM2 antagonist RG7112 on the p53 pathway in patients with MDM2-amplified, well-differentiated or dedifferentiated liposarcoma: An exploratory proof-of-mechanism study. Lancet Oncol. 2012, 13, 1133-1140. [CrossRef]

61. Tovar, C.; Graves, B.; Packman, K.; Filipovic, Z.; Higgins, B.; Xia, M.; Tardell, C.; Garrido, R.; Lee, E.; Kolinsky, K.; et al. MDM2 small-molecule antagonist RG7112 activates p53 signaling and regresses human tumors in preclinical cancer models. Cancer Res. 2013, 73, 2587-2597. [CrossRef] [PubMed]

62. Hu, C.; Li, X.; Wang, W.; Zhang, L.; Tao, L.; Dong, X.; Sheng, R.; Yang, B.; Hu, Y. Design, synthesis, and biological evaluation of imidazoline derivatives as p53-MDM2 binding inhibitors. Bioorg. Med. Chem. 2011, 19, 5454-5461. [CrossRef] [PubMed]

63. Hu, C.; Dou, X.; Wu, Y.; Zhang, L.; Hua, Y. Design, synthesis and CoMFA studies of N1-amino acid substituted 2,4,5-triphenyl imidazoline derivatives as p53-MDM2 binding inhibitors. Bioorg. Med. Chem. 2012, 20, 1417-1424. [CrossRef] [PubMed]

64. Guan, X.; Hu, Y. Imidazoline derivatives: A patent review (2006-present). Expert Opin. Ther. Patents 2012, 22, 1353-1365. [CrossRef] [PubMed]

65. Zak, K.; Pecak, A.; Rys, B.; Wladyka, B.; Doemling, A.; Weber, L.; Holak, T.A.; Dubin, G. MDM2 and MDMX inhibitors for the treatment of cancer: A patent review (2011-present). Expert Opin. Ther. Patents 2013, 23, 425-448. [CrossRef] [PubMed]

66. Miyazaki, M.; Kawato, H.; Naito, H.; Ikeda, M.; Miyazaki, M.; Kitagawa, M.; Seki, T.; Fukutake, S.; Aonuma, M.; Soga, T. Discovery of novel dihydroimidazothiazole derivatives as p53-MDM2 protein-protein interaction inhibitors: Synthesis, biological evaluation and structure-activity relationships. Bioorg. Med. Chem. Lett. 2012, 22, 6338-6342. [CrossRef] [PubMed]

67. Miyazaki, M.; Uoto, K.; Sugimoto, Y.; Naito, H.; Yoshida, K.; Okayama, T.; Kawato, H.; Miyazaki, M.; Kitagawa, M.; Seki, T.; et al. Discovery of DS-5272 as a promising candidate: A potent and orally active p53-MDM2 interaction inhibitor. Bioorg. Med. Chem. 2015, 23, 2360-2367. [CrossRef] [PubMed]

68. Grasberger, B.L.; Lu, T.B.; Schubert, C.; Parks, D.J.; Carver, T.E.; Koblish, H.K.; Cummings, M.D.; LaFrance, L.V.; Milkiewicz, K.L.; Calvo, R.R.; et al. Discovery and cocrystal structure of benzodiazepinedione HDM2 antagonists that activate p53 in cells. J. Med. Chem. 2005, 48, 909-912. [CrossRef] [PubMed]

69. Parks, D.J.; LaFrance, L.V.; Calvo, R.R.; Milkiewicz, K.L.; Gupta, V.; Lattanze, J.; Ramachandren, K.; Carver, T.E.; Petrella, E.C.; Cummings, M.D.; et al. 1,4-benzodiazepine-2,5-diones as small molecule antagonists of the HDM2-p53 interaction: Discovery and sar. Bioorg. Med. Chem. Lett. 2005, 15, 765-770. [CrossRef] [PubMed]

70. Cummings, M.D.; Schubert, C.; Parks, D.J.; Calvo, R.R.; LaFrance, L.V.; Lattanze, J.; Milkiewicz, K.L.; Lu, T.B. Substituted 1,4-benzodiazepine-2,5-diones as alpha-helix mimetic antagonists of the HDM2-p53 protein-protein interaction. Chem. Biol. Drug Des. 2006, 67, 201-205. [CrossRef] [PubMed]

71. Bissantz, C.; Kuhn, B.; Stahl, M. A medicinal chemist's guide to molecular interactions. J. Med. Chem. 2010, 53, 5061-5084. [CrossRef] [PubMed]

72. Raboisson, P.; Marugan, J.J.; Schubert, C.; Koblish, H.K.; Lu, T.B.; Zhao, S.Y.; Player, M.R.; Maroney, A.C.; Reed, R.L.; Huebert, N.D.; et al. Structure-based design, synthesis, and biological evaluation of novel 1,4-diazepines as HDM2 antagonists. Bioorg. Med. Chem. Lett. 2005, 15, 1857-1861. [CrossRef] [PubMed]

73. Parks, D.J.; LaFrance, L.V.; Calvo, R.R.; Milkiewicz, K.L.; Marugan, J.J.; Raboisson, P.; Schubert, C.; Koblish, H.K.; Zhao, S.Y.; Franks, C.F.; et al. Enhanced pharmacokinetic properties of 1,4-benzodiazepine-2,5-dione antagonists of the HDM2-p53 protein-protein interaction through structure-based drug design. Bioorg. Med. Chem. Lett. 2006, 16, 3310-3314. [CrossRef] [PubMed]

74. Leonard, K.; Marugan, J.J.; Raboisson, P.; Calvo, R.; Gushue, J.M.; Koblish, H.K.; Lattanze, J.; Zhao, S.Y.; Cummings, M.D.; Player, M.R.; et al. Novel 1,4-benzodiazepine-2,5-diones as HDM2 antagonists with improved cellular activity. Bioorg. Med. Chem. Lett. 2006, 16, 3463-3468. [CrossRef] [PubMed]

75. Marugan, J.J.; Leonard, K.; Raboisson, P.; Gushue, J.M.; Calvo, R.; Koblish, H.K.; Lattanze, J.; Zhao, S.Y.; Cummings, M.D.; Player, M.R.; et al. Enantiomerically pure 1,4-benzodiazepine-2,5-diones as HDM2 antagonists. Bioorg. Med. Chem. Lett. 2006, 16, 3115-3120. [CrossRef] [PubMed] 
76. Koblish, H.K.; Zhao, S.Y.; Franks, C.F.; Donatelli, R.R.; Tominovich, R.M.; LaFrance, L.V.; Leonard, K.A.; Gushue, J.M.; Parks, D.J.; Calvo, R.R.; et al. Benzodiazepinedione inhibitors of the HDM2: P53 complex suppress human tumor cell proliferation in vitro and sensitize tumors to doxorubicin in vivo. Mol. Cancer Ther. 2006, 5, 160-169. [CrossRef] [PubMed]

77. Huang, Y.; Wolf, S.; Bista, M.; Meireles, L.; Camacho, C.; Holak, T.A.; Doemling, A. 1,4-thienodiazepine-2,5-diones via MCR (I): Synthesis, virtual space and p53-MDM2 activity. Chem. Biol. Drug Des. 2010, 76, 116-129. [CrossRef] [PubMed]

78. Zhuang, C.; Miao, Z.; Zhu, L.; Zhang, Y.; Guo, Z.; Yao, J.; Dong, G.; Wang, S.; Liu, Y.; Chen, H.; et al. Synthesis and biological evaluation of thio-benzodiazepines as novel small molecule inhibitors of the p53-MDM2 protein-protein interaction. Eur. J. Med. Chem. 2011, 46, 5654-5661. [CrossRef] [PubMed]

79. Guo, Z.; Zhuang, C.; Zhu, L.; Zhang, Y.; Yao, J.; Dong, G.; Wang, S.; Liu, Y.; Chen, H.; Sheng, C.; et al. Structure-activity relationship and antitumor activity of thio-benzodiazepines as p53-MDM2 protein-protein interaction inhibitors. Eur. J. Med. Chem. 2012, 56, 10-16. [CrossRef] [PubMed]

80. Yu, Z.; Zhuang, C.; Wu, Y.; Guo, Z.; Li, J.; Dong, G.; Yao, J.; Sheng, C.; Miao, Z.; Zhang, W. Design, synthesis and biological evaluation of sulfamide and triazole benzodiazepines as novel p53-MDM2 inhibitors. Int. J. Mol. Sci. 2014, 15, 15741-15753. [CrossRef] [PubMed]

81. Hardcastle, I.R.; Ahmed, S.U.; Atkins, H.; Calvert, A.H.; Curtin, N.J.; Farnie, G.; Golding, B.T.; Griffin, R.J.; Guyenne, S.; Hutton, C.; et al. Isoindolinone-based inhibitors of the MDM2-p53 protein-protein interaction. Bioorg. Med. Chem. Lett. 2005, 15, 1515-1520. [CrossRef] [PubMed]

82. Hardcastle, I.R.; Ahmed, S.U.; Atkins, H.; Farnie, G.; Golding, B.T.; Griffin, R.J.; Guyenne, S.; Hutton, C.; Kallblad, P.; Kemp, S.J.; et al. Small-molecule inhibitors of the MDM2-p53 protein-protein interaction based on an isoindolinone scaffold. J. Med. Chem. 2006, 49, 6209-6221. [CrossRef] [PubMed]

83. Riedinger, C.; Endicott, J.A.; Kemp, S.J.; Smyth, L.A.; Watson, A.; Valeur, E.; Golding, B.T.; Griffin, R.J.; Hardcastle, I.R.; Noble, M.E.; et al. Analysis of chemical shift changes reveals the binding modes of isoindolinone inhibitors of the MDM2-p53 interaction. J. Am. Chem. Soc. 2008, 130, 16038-16044. [CrossRef] [PubMed]

84. Hardcastle, I.R.; Liu, J.; Valeur, E.; Watson, A.; Ahmed, S.U.; Blackburn, T.J.; Bennaceur, K.; Clegg, W.; Drummond, C.; Endicott, J.A.; et al. Isoindolinone inhibitors of the murine double minute 2 (MDM2)-p53 protein-protein interaction: Structure-activity studies leading to improved potency. J. Med. Chem. 2011, 54, 1233-1243. [CrossRef] [PubMed]

85. Riedinger, C.; Noble, M.E.; Wright, D.J.; Mulks, F.; Hardcastle, I.R.; Endicott, J.A.; McDonnell, J.M. Understanding small-molecule binding to MDM2: Insights into structural effects of isoindolinone inhibitors from NMR spectroscopy. Chem. Biol. Drug Des. 2011, 77, 301-308. [CrossRef] [PubMed]

86. Watson, A.F.; Liu, J.; Bennaceur, K.; Drummond, C.J.; Endicott, J.A.; Golding, B.T.; Griffin, R.J.; Haggerty, K.; Lu, X.; McDonnell, J.M.; et al. MDM2-p53 protein-protein interaction inhibitors: A-ring substituted isoindolinones. Bioorg. Med. Chem. Lett. 2011, 21, 5916-5919. [CrossRef] [PubMed]

87. Soares, J.; Pereira, N.A.L.; Monteiro, A.; Leao, M.; Bessa, C.; dos Santos, D.; Rairnundo, L.; Queiroz, G.; Bisio, A.; Inga, A.; et al. Oxazoloisoindolinones with in vitro antitumor activity selectively activate a p53-pathway through potential inhibition of the p53-MDM2 interaction. Eur. J. Pharm. Sci. 2015, 66, 138-147. [CrossRef] [PubMed]

88. Allen, J.G.; Bourbeau, M.P.; Wohlhieter, G.E.; Bartberger, M.D.; Michelsen, K.; Hungate, R.; Gadwood, R.C.; Gaston, R.D.; Evans, B.; Mann, L.W.; et al. Discovery and optimization of chromenotriazolopyrimidines as potent inhibitors of the mouse double minute 2-tumor protein 53 protein-protein interaction. J. Med. Chem. 2009, 52, 7044-7053. [CrossRef] [PubMed]

89. Beck, H.P.; DeGraffenreid, M.; Fox, B.; Allen, J.G.; Rew, Y.; Schneider, S.; Saiki, A.Y.; Yu, D.Y.; Oliner, J.D.; Salyers, K.; et al. Improvement of the synthesis and pharmacokinetic properties of chromenotriazolopyrimidine MDM2-p53 protein-protein inhibitors. Bioorg. Med. Chem. Lett. 2011, 21, 2752-2755. [CrossRef] [PubMed]

90. Ding, K.; Lu, Y.; Nikolovska-Coleska, Z.; Qiu, S.; Ding, Y.S.; Gao, W.; Stuckey, J.; Krajewski, K.; Roller, P.P.; Tomita, Y.; et al. Structure-based design of potent non-peptide MDM2 inhibitors. J. Am. Chem. Soc. 2005, 127, 10130-10131. [CrossRef] [PubMed] 
91. Ding, K.; Lu, Y.; Nikolovska-Coleska, Z.; Wang, G.; Qiu, S.; Shangary, S.; Gao, W.; Qin, D.; Stuckey, J.; Krajewski, K.; et al. Structure-based design of spiro-oxindoles as potent, specific small-molecule inhibitors of the MDM2-p53 interaction. J. Med. Chem. 2006, 49, 3432-3435. [CrossRef] [PubMed]

92. Ding, K.; Wang, G.P.; Deschamps, J.R.; Parrish, D.A.; Wang, S.M. Synthesis of spirooxindoles via asymmetric 1,3-dipolar cycloaddition. Tetrahedron Lett. 2005, 46, 5949-5951. [CrossRef]

93. Yu, S.; Qin, D.; Shangary, S.; Chen, J.; Wang, G.; Ding, K.; McEachern, D.; Qiu, S.; Nikolovska-Coleska, Z.; Miller, R.; et al. Potent and orally active small-molecule inhibitors of the MDM2-p53 interaction. J. Med. Chem. 2009, 52, 7970-7973. [CrossRef] [PubMed]

94. Shangary, S.; Qin, D.; McEachern, D.; Liu, M.; Miller, R.S.; Qiu, S.; Nikolovska-Coleska, Z.; Ding, K.; Wang, G.; Chen, J.; et al. Temporal activation of p53 by a specific MDM2 inhibitor is selectively toxic to tumors and leads to complete tumor growth inhibition. Proc. Natl. Acad. Sci. USA 2008, 105, 3933-3938. [CrossRef] [PubMed]

95. Zhao, Y.; Yu, S.; Sun, W.; Liu, L.; Lu, J.; McEachern, D.; Shargary, S.; Bernard, D.; Li, X.; Zhao, T.; et al. A potent small-molecule inhibitor of the MDM2-p53 interaction (MI-888) achieved complete and durable tumor regression in mice. J. Med. Chem. 2013, 56, 5553-5561. [CrossRef] [PubMed]

96. Wang, S.; Sun, W.; Zhao, Y.; McEachern, D.; Meaux, I.; Barriere, C.; Stuckey, J.A.; Meagher, J.L.; Bai, L.; Liu, L.; et al. SAR405838: An optimized inhibitor of MDM2-p53 interaction that induces complete and durable tumor regression. Cancer Res. 2014, 74, 5855-5865. [CrossRef] [PubMed]

97. Zhao, Y.; Liu, L.; Sun, W.; Lu, J.; McEachern, D.; Li, X.; Yu, S.; Bernard, D.; Ochsenbein, P.; Ferey, V.; et al. Diastereomeric spirooxindoles as highly potent and efficacious MDM2 inhibitors. J. Am. Chem. Soc. 2013, 135, 7223-7234. [CrossRef] [PubMed]

98. Aguilar, A.; Sun, W.; Liu, L.; Lu, J.; McEachern, D.; Bernard, D.; Deschamps, J.R.; Wang, S. Design of chemically stable, potent, and efficacious MDM2 inhibitors that exploit the retro-mannich ring-opening-cyclization reaction mechanism in spiro-oxindoles. J. Med. Chem. 2014, 57, 10486-10498. [CrossRef] [PubMed]

99. Zhang, Z.; Ding, Q.; Liu, J.-J.; Zhang, J.; Jiang, N.; Chu, X.-J.; Bartkovitz, D.; Luk, K.-C.; Janson, C.; Tovar, C.; et al. Discovery of potent and selective spiroindolinone MDM2 inhibitor, RO8994, for cancer therapy. Bioorg. Med. Chem. 2014, 22, 4001-4009. [CrossRef] [PubMed]

100. Shu, L.H.; Li, Z.Z.; Gu, C.; Fishlock, D. Synthesis of a spiroindolinone pyrrolidinecarboxamide MDM2 antagonist. Org. Process Res. Dev. 2013, 17, 247-256. [CrossRef]

101. Zhang, Z.; Chu, X.-J.; Liu, J.-J.; Ding, Q.; Zhang, J.; Bartkovitz, D.; Jiang, N.; Karnachi, P.; So, S.-S.; Tovar, C.; et al. Discovery of potent and orally active p53-MDM2 inhibitors RO5353 and RO2468 for potential clinical development. ACS Med. Chem. Lett. 2014, 5, 124-127. [CrossRef] [PubMed]

102. Gomez-Monterrey, I.; Bertamino, A.; Porta, A.; Carotenuto, A.; Musella, S.; Aquino, C.; Granata, I.; Sala, M.; Brancaccio, D.; Picone, D.; et al. Identification of the spiro(oxindole-3, $3^{\prime}$-thiazolidine)-based derivatives as potential p53 activity modulators. J. Med. Chem. 2010, 53, 8319-8329. [CrossRef] [PubMed]

103. Costa, B.; Bendinelli, S.; Gabelloni, P.; Da Pozzo, E.; Daniele, S.; Scatena, F.; Vanacore, R.; Campiglia, P.; Bertamino, A.; Gomez-Monterrey, I.; et al. Human glioblastoma multiforme: p53 reactivation by a novel MDM2 inhibitor. PLoS ONE 2013, 8, e72281. [CrossRef] [PubMed]

104. Bertamino, A.; Soprano, M.; Musella, S.; Rusciano, M.R.; Sala, M.; Vernieri, E.; di Sarno, V.; Limatola, A.; Carotenuto, A.; Cosconati, S.; et al. Synthesis, in vitro, and in cell studies of a new series of indoline-3,2'-thiazolidine-based p53 modulators. J. Med. Chem. 2013, 56, 5407-5421. [CrossRef] [PubMed]

105. Sorriento, D.; del Giudice, C.; Bertamino, A.; Ciccarelli, M.; Gomez-Monterrey, I.; Campiglia, P.; Novellino, E.; Illario, M.; Trimarco, B.; de Luca, N.; et al. New small molecules, ISA27 and SM13, inhibit tumour growth inducing mitochondrial effects of p53. Br. J. Cancer 2015, 112, 77-85. [CrossRef] [PubMed]

106. Kumar, A.; Gupta, G.; Bishnoi, A.K.; Saxena, R.; Saini, K.S.; Konwar, R.; Kumar, S.; Dwivedi, A. Design and synthesis of new bioisosteres of spirooxindoles (MI-63/219) as anti-breast cancer agents. Bioorg. Med. Chem. 2015, 23, 839-848. [CrossRef] [PubMed]

107. Ivanenkov, Y.A.; Vasilevski, S.V.; Beloglazkina, E.K.; Kukushkin, M.E.; Machulkin, A.E.; Veselov, M.S.; Chufarova, N.V.; Chernyaginab, E.S.; Vanzcool, A.S.; Zyk, N.V.; et al. Design, synthesis and biological evaluation of novel potent MDM2/p53 small-molecule inhibitors. Bioorg. Med. Chem. Lett. 2015, 25, 404-409. [CrossRef] [PubMed] 
108. Ribeiro, C.J.A.; Kumar, S.P.; Moreira, R.; Santos, M.M.M. Efficient synthesis of spiroisoxazoline oxindoles. Tetrahedron Lett. 2012, 53, 281-284. [CrossRef]

109. Ribeiro, C.J.A.; Amaral, J.D.; Rodrigues, C.M.P.; Moreira, R.; Santos, M.M.M. Synthesis and evaluation of spiroisoxazoline oxindoles as anticancer agents. Bioorg. Med. Chem. 2014, 22, 577-584. [CrossRef] [PubMed]

110. Ribeiro, C.J.A.; Amaral, J.D.; Rodrigues, C.M.P.; Moreira, R.; Santos, M.M.M. Spirooxadiazoline oxindoles with promising in vitro antitumor activities. Med. Chem. Comm. 2016, 7, 420-425. [CrossRef]

111. Monteiro, A.; Goncalves, L.M.; Santos, M.M.M. Synthesis of novel spiropyrazoline oxindoles and evaluation of cytotoxicity in cancer cell lines. Eur. J. Med. Chem. 2014, 79, 266-272. [CrossRef] [PubMed]

112. Santos, M.M.M. Recent advances in the synthesis of biologically active spirooxindoles. Tetrahedron 2014, 70, 9735-9757. [CrossRef]

113. Czarna, A.; Beck, B.; Srivastava, S.; Popowicz, G.M.; Wolf, S.; Huang, Y.; Bista, M.; Holak, T.A.; Doemling, A. Robust generation of lead compounds for protein-protein interactions by computational and mcr chemistry: P53/HDM2 antagonists. Angew. Chem. Int. Ed. 2010, 49, 5352-5356. [CrossRef] [PubMed]

114. Popowicz, G.M.; Czarna, A.; Wolf, S.; Wang, K.; Wang, W.; Domling, A.; Holak, T.A. Structures of low molecular weight inhibitors bound to MDMX and MDM2 reveal new approaches for p53-MDMX/MDM2 antagonist drug discovery. Cell Cycle 2010, 9, 1104-1111. [CrossRef] [PubMed]

115. Huang, Y.J.; Wolf, S.; Koes, D.; Popowicz, G.M.; Camacho, C.J.; Holak, T.A.; Domling, A. Exhaustive fluorine scanning toward potent p53-MDM2 antagonists. ChemMedChem 2012, 7, 49-52. [CrossRef] [PubMed]

116. Ding, Q.; Zhang, Z.; Liu, J.-J.; Jiang, N.; Zhang, J.; Ross, T.M.; Chu, X.-J.; Bartkovitz, D.; Podlaski, F.; Janson, C.; et al. Discovery of RG7388, a potent and selective p53-MDM2 inhibitor in clinical development. J. Med. Chem. 2013, 56, 5979-5983. [CrossRef] [PubMed]

117. Higgins, B.; Glenn, K.; Walz, A.; Tovar, C.; Filipovic, Z.; Hussain, S.; Lee, E.; Kolinsky, K.; Tannu, S.; Adames, V.; et al. Preclinical optimization of MDM2 antagonist scheduling for cancer treatment by using a model-based approach. Clin. Cancer Res. 2014, 20, 3742-3752. [CrossRef] [PubMed]

118. De Turiso, F.G.-L.; Sun, D.; Rew, Y.; Bartberger, M.D.; Beck, H.P.; Canon, J.; Chen, A.; Chow, D.; Correll, T.L.; Huang, X.; et al. Rational design and binding mode duality of MDM2-p53 inhibitors. J. Med. Chem. 2013, 56, 4053-4070. [CrossRef] [PubMed]

119. Rew, Y.; Sun, D.; de Turiso, F.G.-L.; Bartberger, M.D.; Beck, H.P.; Canon, J.; Chen, A.; Chow, D.; Deignan, J.; Fox, B.M.; et al. Structure-based design of novel inhibitors of the MDM2-p53 interaction. J. Med. Chem. 2012, 55, 4936-4954. [CrossRef] [PubMed]

120. Michelsen, K.; Jordan, J.B.; Lewis, J.; Long, A.M.; Yang, E.; Rew, Y.; Zhou, J.; Yakowec, P.; Schnier, P.D.; Huang, X.; et al. Ordering of the N-terminus of human MDM2 by small molecule inhibitors. J. Am. Chem. Soc. 2012, 134, 17059-17067. [CrossRef] [PubMed]

121. Rew, Y.; Sun, D. Discovery of a small molecule MDM2 inhibitor (AMG 232) for treating cancer. J. Med. Chem. 2014, 57, 6332-6341. [CrossRef] [PubMed]

122. Lucas, B.S.; Fisher, B.; McGee, L.R.; Olson, S.H.; Medina, J.C.; Cheung, E. An expeditious synthesis of the MDM2-p53 inhibitor AM-8553. J. Am. Chem. Soc. 2012, 134, 12855-12860. [CrossRef] [PubMed]

123. Bernard, D.; Zhao, Y.; Wang, S. AM-8553: A novel MDM2 inhibitor with a promising outlook for potential clinical development. J. Med. Chem. 2012, 55, 4934-4935. [CrossRef] [PubMed]

124. Sun, D.; Li, Z.; Rew, Y.; Gribble, M.; Bartberger, M.D.; Beck, H.P.; Canon, J.; Chen, A.; Chen, X.; Chow, D.; et al . Discovery of AMG 232, a potent, selective, and orally bioavailable MDM2-p53 inhibitor in clinical development. J. Med. Chem. 2014, 57, 1454-1472. [CrossRef] [PubMed]

125. Wang, Y.; Zhu, J.; Liu, J.; Chen, X.; Mihalic, J.; Deignan, J.; Yu, M.; Sun, D.; Kayser, F.; McGee, L.R.; et al. Optimization beyond AMG 232: Discovery and SAR of sulfonamides on a piperidinone scaffold as potent inhibitors of the MDM2-p53 protein-protein interaction. Bioorg. Med. Chem. Lett. 2014, 24, 3782-3785. [CrossRef] [PubMed]

126. Yu, M.; Wang, Y.; Zhu, J.; Bartberger, M.D.; Canon, J.; Chen, A.; Chow, D.; Eksterowicz, J.; Fox, B.; Fu, J.; et al. Discovery of potent and simplified piperidinone-based inhibitors of the MDM2-p53 interaction. ACS Med. Chem. Lett. 2014, 5, 894-899. [CrossRef] [PubMed]

127. Canon, J.; Osgood, T.; Olson, S.H.; Saiki, A.Y.; Robertson, R.; Yu, D.; Eksterowicz, J.; Ye, Q.; Jin, L.; Chen, A.; et al. The MDM2 inhibitor AMG 232 demonstrates robust antitumor efficacy and potentiates the activity of p53-inducing cytotoxic agents. Mol. Cancer Ther. 2015, 14, 649-658. [CrossRef] [PubMed] 
128. Gonzalez, A.Z.; Li, Z.H.; Beck, H.P.; Canon, J.; Chen, A.; Chow, D.; Duquette, J.; Eksterowicz, J.; Fox, B.M.; $\mathrm{Fu}$, J.S.; et al. Novel inhibitors of the MDM2-p53 interaction featuring hydrogen bond acceptors as carboxylic acid isosteres. J. Med. Chem. 2014, 57, 2963-2988. [CrossRef] [PubMed]

129. Rew, Y.; Sun, D.Q.; Yan, X.L.; Beck, H.P.; Canon, J.; Chen, A.; Duquette, J.; Eksterowicz, J.; Fox, B.M.; Fu, J.S.; et al. Discovery of AM-7209, a potent and selective 4-amidobenzoic acid inhibitor of the MDM2-p53 interaction. J. Med. Chem. 2014, 57, 10499-10511. [CrossRef] [PubMed]

130. Gonzalez, A.Z.; Eksterowicz, J.; Bartberger, M.D.; Beck, H.P.; Canon, J.; Chen, A.; Chow, D.; Duquette, J.; Fox, B.M.; Fu, J.; et al. Selective and potent morpholinone inhibitors of the MDM2-p53 protein-protein interaction. J. Med. Chem. 2014, 57, 2472-2488. [CrossRef] [PubMed]

131. Gessier, F.; Kallen, J.; Jacoby, E.; Chène, P.; Stachyra-Valat, T.; Ruetz, S.; Jeay, S.; Holzer, P.; Masuya, K.; Furet, P. Discovery of dihydroisoquinolinone derivatives as novel inhibitors of the p53-MDM2 interaction with a distinct binding mode. Bioorg. Med. Chem. Lett. 2015, 17, 3621-3625. [CrossRef] [PubMed]

132. Chen, L.H.; Yin, H.; Farooqi, B.; Sebti, S.; Hamilton, A.D.; Chen, J.D. P53 alpha-helix mimetics antagonize p53/MDM2 interaction and activate p53. Mol. Cancer Ther. 2005, 4, 1019-1025. [CrossRef] [PubMed]

133. Yin, H.; Lee, G.I.; Park, H.S.; Payne, G.A.; Rodriguez, J.M.; Sebti, S.M.; Hamilton, A.D. Terphenyl-based helical mimetics that disrupt the p53/HDM2 interaction. Angew. Chem. Int. Ed. 2005, 44, 2704-2707. [CrossRef] [PubMed]

134. Zhuang, C.; Miao, Z.; Zhu, L.; Dong, G.; Guo, Z.; Wang, S.; Zhang, Y.; Wu, Y.; Yao, J.; Sheng, C.; et al. Discovery, synthesis, and biological evaluation of orally active pyrrolidone derivatives as novel inhibitors of p53-MDM2 protein-protein interaction. J. Med. Chem. 2012, 55, 9630-9642. [CrossRef] [PubMed]

135. Li, J.; Wu, Y.; Guo, Z.; Zhuang, C.; Yao, J.; Dong, G.; Yu, Z.; Min, X.; Wang, S.; Liu, Y.; et al. Discovery of 1-arylpyrrolidone derivatives as potent p53-MDM2 inhibitors based on molecule fusing strategy. Bioorg. Med. Chem. Lett. 2014, 24, 2648-2650. [CrossRef] [PubMed]

136. Zhuang, C.; Miao, Z.; Wu, Y.; Guo, Z.; Li, J.; Yao, J.; Xing, C.; Sheng, C.; Zhang, W. Double-edged swords as cancer therapeutics: Novel, orally active, small molecules simultaneously inhibit p53-MDM2 interaction and the NF-kappaB pathway. J. Med. Chem. 2014, 57, 567-577. [CrossRef] [PubMed]

137. Zhuang, C.; Sheng, C.; Shin, W.S.; Wu, Y.; Li, J.; Yao, J.; Dong, G.; Zhang, W.; Sham, Y.Y.; Miao, Z.; et al. A novel drug discovery strategy: Mechanistic investigation of an enantiomeric antitumor agent targeting dual p53 and NF-kB pathways. Oncotarget 2014, 5, 10830-10839. [CrossRef] [PubMed]

138. Ma, Y.; Lahue, B.R.; Shipps, G.W., Jr.; Brookes, J.; Wang, Y. Substituted piperidines as HDM2 inhibitors. Bioorg. Med. Chem. Lett. 2014, 24, 1026-1030. [CrossRef] [PubMed]

139. Pan, W.; Lahue, B.R.; Ma, Y.; Nair, L.G.; Shipps, G.W., Jr.; Wang, Y.; Doll, R.; Bogen, S.L. Core modification of substituted piperidines as novel inhibitors of HDM2-p53 protein-protein interaction. Bioorg. Med. Chem. Lett. 2014, 24, 1983-1986. [CrossRef] [PubMed]

140. Ma, Y.; Lahue, B.R.; Gibeau, C.R.; Shipps, G.W.; Bogen, S.L.; Wang, Y.L.; Guo, Z.Y.; Guzi, T.J. Pivotal role of an aliphatic side chain in the development of an HDM2 inhibitor. ACS Med. Chem. Lett. 2014, 5, 572-575. [CrossRef] [PubMed]

141. Zheng, G.-H.; Shen, J.-J.; Zhan, Y.-C.; Yi, H.; Xue, S.-T.; Wang, Z.; Ji, X.-Y.; Li, Z.-R. Design, synthesis and in vitro and in vivo antitumour activity of 3-benzylideneindolin-2-one derivatives, a novel class of small-molecule inhibitors of the MDM2-p53 interaction. Eur. J. Med. Chem. 2014, 81, 277-288. [CrossRef] [PubMed]

142. Lu, Y.P.; Nikolovska-Coleska, Z.; Fang, X.L.; Gao, W.; Shangary, S.; Qiu, S.; Qin, D.G.; Wang, S.M. Discovery of a nanomolar inhibitor of the human murine double minute 2 (MDM2)-p53 interaction through an integrated, virtual database screening strategy. J. Med. Chem. 2006, 49, 3759-3762. [CrossRef] [PubMed]

143. Bowman, A.L.; Nikolovska-Coleska, Z.; Zhong, H.; Wang, S.; Carlson, H.A. Small molecule inhibitors of the MDM2-p53 interaction discovered by ensemble-based receptor models. J. Am. Chem. Soc. 2007, 129, 12809-12814. [CrossRef] [PubMed]

144. Vaupel, A.; Bold, G.; de Pover, A.; Stachyra-Valat, T.; Hergovich-Lisztwan, J.; Kallen, J.; Masuya, K.; Furet, P. Tetra-substituted imidazoles as a new class of inhibitors of the p53-MDM2 interaction. Bioorg. Med. Chem. Lett. 2014, 24, 2110-2114. [CrossRef] [PubMed]

145. Shvarts, A.; Steegenga, W.T.; Riteco, N.; van Laar, T.; Dekker, P.; Bazuine, M.; van Ham, R.C.A.; van Oordt, W.V.; Hateboer, G.; van der Eb, A.J.; et al. MDMX: A novel p53-binding protein with some functional properties of MDM2. EMBO J. 1996, 15, 5349-5357. [PubMed] 
146. Marine, J.C.; Jochemsen, A.G. MDMX as an essential regulator of p53 activity. Biochem. Biophys. Res. Commun. 2005, 331, 750-760. [CrossRef] [PubMed]

147. Wade, M.; Li, Y.-C.; Wahl, G.M. MDM2, MDMX and p53 in oncogenesis and cancer therapy. Nat. Rev. Cancer 2013, 13, 83-96. [CrossRef] [PubMed]

148. Garcia, D.; Warr, M.R.; Martins, C.P.; Swigart, L.B.; Passegue, E.; Evan, G.I. Validation of MDMX as a therapeutic target for reactivating p53 in tumors. Genes Dev. 2011, 25, 1746-1757. [CrossRef] [PubMed]

149. Reed, D.; Shen, Y.; Shelat, A.A.; Arnold, L.A.; Ferreira, A.M.; Zhu, F.; Mills, N.; Smithson, D.C.; Regni, C.A.; Bashford, D.; et al. Identification and characterization of the first small molecule inhibitor of MDMX. J. Biol. Chem. 2010, 285, 10786-10796. [CrossRef] [PubMed]

150. Bista, M.; Smithson, D.; Pecak, A.; Salinas, G.; Pustelny, K.; Min, J.; Pirog, A.; Finch, K.; Zdzalik, M.; Waddell, B.; et al. On the mechanism of action of SJ-172550 in inhibiting the interaction of MDM4 and p53. PLoS ONE 2012, 7, e37518. [CrossRef] [PubMed]

151. Berkson, R.G.; Hollick, J.J.; Westwood, N.J.; Woods, J.A.; Lane, D.P.; Lain, S. Pilot screening programme for small molecule activators of p53. Int. J. Cancer 2005, 115, 701-710. [CrossRef] [PubMed]

152. Wang, H.; Yan, C. A small-molecule p53 activator induces apoptosis through inhibiting MDMX expression in breast cancer cells. Neoplasia 2011, 13, 611-619. [CrossRef] [PubMed]

153. Roh, J.-L.; Park, J.Y.; Kim, E.H. XI-011 enhances cisplatin-induced apoptosis by functional restoration of p53 in head and neck cancer. Apoptosis 2014, 19, 1594-1602. [CrossRef] [PubMed]

154. Graves, B.; Thompson, T.; Xia, M.; Janson, C.; Lukacs, C.; Deo, D.; di Lello, P.; Fry, D.; Garvie, C.; Huang, K.-S.; et al. Activation of the p53 pathway by small-molecule-induced MDM2 and MDMX dimerization. Proc. Natl. Acad. Sci. USA 2012, 109, 11788-11793. [CrossRef] [PubMed]

155. Soares, J.; Raimundo, L.; Pereira, N.A.L.; dos Santos, D.J.V.A.; Perez, M.; Queiroz, G.; Leao, M.; Santos, M.M.M.; Saraiva, L. A tryptophanol-derived oxazolopiperidone lactam is cytotoxic against tumors via inhibition of p53 interaction with murine double minute proteins. Pharmacol. Res. 2015, 95-96, 42-52. [CrossRef] [PubMed]

156. Blackburn, T.J.; Ahmed, S.; Coxon, C.R.; Liu, J.; Lu, X.; Golding, B.T.; Griffin, R.J.; Hutton, C.; Newell, D.R.; Ojo, S.; et al. Diaryl- and triaryl-pyrrole derivatives: Inhibitors of the MDM2-p53 and MDMX-p53 protein-protein interactions. Med. Chem. Commun. 2013, 4, 1297-1304. [CrossRef] [PubMed]

157. Neochoritis, C.G.; Wang, K.; Estrada-Ortiz, N.; Herdtweck, E.; Kubica, K.; Twarda, A.; Zak, K.M.; Holak, T.A.; Domling, A. 2,3'-bis (1'H-indole) heterocycles: New p53/MDM2/MDMX antagonists. Bioorg. Med. Chem. Lett. 2015, 25, 5661-5666. [CrossRef] [PubMed]

158. Muller, P.A.J.; Vousden, K.H. Mutant p53 in cancer: New functions and therapeutic opportunities. Cancer Cell 2014, 25, 304-317. [CrossRef] [PubMed]

159. Bykov, V.J.N.; Wiman, K.G. Mutant p53 reactivation by small molecules makes its way to the clinic. FEBS Lett. 2014, 588, 2622-2627. [CrossRef] [PubMed]

160. Bou-Hanna, C.; Jarry, A.; Lode, L.; Schmitz, I.; Schulze-Osthoff, K.; Kury, S.; Bezieau, S.; Mosnier, J.-F.; Laboisse, C.L. Acute cytotoxicity of MIRA-1/NSC19630, a mutant p53-reactivating small molecule, against human normal and cancer cells via a caspase-9-dependent apoptosis. Cancer Lett. 2015, 359, 211-217. [CrossRef] [PubMed]

161. Issaeva, N.; Bozko, P.; Enge, M.; Protopopova, M.; Verhoef, L.; Masucci, M.; Pramanik, A.; Selivanova, G. Small molecule RITA binds to p53, blocks p53-HDM-2 interaction and activates p53 function in tumors. Nat. Med. 2004, 10, 1321-1328. [CrossRef] [PubMed]

162. Krajewski, M.; Ozdowy, P.; D'Silva, L.; Rothweiler, U.; Holak, T.A. NMR indicates that the small molecule RITA does not block p53-MDM2 binding in vitro. Nat. Med. 2005, 11, 1135-1136. [CrossRef] [PubMed]

163. Zhao, C.Y.; Grinkevich, V.V.; Nikulenkov, F.; Bao, W.; Selivanova, G. Rescue of the apoptotic-inducing function of mutant p53 by small molecule RITA. Cell Cycle 2010, 9, 1847-1855. [CrossRef] [PubMed]

164. Burmakin, M.; Shi, Y.; Hedstrom, E.; Kogner, P.; Selivanova, G. Dual targeting of wild-type and mutant p53 by small molecule RITA results in the inhibition of $N$-Myc and key survival oncogenes and kills neuroblastoma cells in vivo and in vitro. Clin. Cancer Res. 2013, 19, 5092-5103. [CrossRef] [PubMed]

165. Spinnler, C.; Hedstrom, E.; Li, H.; de Lange, J.; Nikulenkov, F.; Teunisse, A.F.A.S.; Verlaan-de Vries, M.; Grinkevich, V.; Jochemsen, A.G.; Selivanova, G. Abrogation of Wip1 expression by RITA-activated p53 potentiates apoptosis induction via activation of ATM and inhibition of HDMX. Cell Death Differ. 2011, 18, 1736-1745. [CrossRef] [PubMed] 
166. Lin, J.; Jin, X.; Bu, Y.; Cao, D.; Zhang, N.; Li, S.; Sun, Q.; Tan, C.; Gao, C.; Jiang, Y. Efficient synthesis of RITA and its analogues: Derivation of analogues with improved antiproliferative activity via modulation of p53/MIR-34a pathway. Org. Biomol. Chem. 2012, 10, 9734-9746. [CrossRef] [PubMed]

167. Jiang, J.; Ding, C.; Li, L.; Gao, C.; Jiang, Y.; Tan, C.; Hua, R. Synthesis and antiproliferative activity of RITA and its analogs. Tetrahedron Lett. 2014, 55, 6635-6638. [CrossRef]

168. Boeckler, F.M.; Joerger, A.C.; Jaggi, G.; Rutherford, T.J.; Veprintsev, D.B.; Fersht, A.R. Targeted rescue of a destabilized mutant of p53 by an in silico screened drug. Proc. Natl. Acad. Sci. USA 2008, 105, 10360-10365. [CrossRef] [PubMed]

169. Wilcken, R.; Liu, X.; Zimmermann, M.O.; Rutherford, T.J.; Fersht, A.R.; Joerger, A.C.; Boeckler, F.M. Halogen-enriched fragment libraries as leads for drug rescue of mutant p53. J. Am. Chem. Soc. 2012, 134, 6810-6818. [CrossRef] [PubMed]

170. Liu, X.; Wilcken, R.; Joerger, A.C.; Chuckowree, I.S.; Amin, J.; Spencer, J.; Fersht, A.R. Small molecule induced reactivation of mutant p53 in cancer cells. Nucleic Acids Res. 2013, 41, 6034-6044. [CrossRef] [PubMed]

171. Bykov, V.J.N.; Issaeva, N.; Shilov, A.; Hultcrantz, M.; Pugacheva, E.; Chumakov, P.; Bergman, J.; Wiman, K.G.; Selivanova, G. Restoration of the tumor suppressor function to mutant p53 by a low-molecular-weight compound. Nat. Med. 2002, 8, 282-288. [CrossRef] [PubMed]

172. Lambert, J.M.R.; Gorzov, P.; Veprintsev, D.B.; Soderqvist, M.; Segerback, D.; Bergman, J.; Fersht, A.R.; Hainaut, P.; Wiman, K.G.; Bykov, V.J.N. PRIMA-1 reactivates mutant p53 by covalent binding to the core domain. Cancer Cell 2009, 15, 376-388. [CrossRef] [PubMed]

173. Ding, L.; Zhang, Z.; Liang, G.; Yao, Z.; Wu, H.; Wang, B.; Zhang, J.; Tariq, M.; Ying, M.; Yang, B. SAHA triggered MET activation contributes to SAHA tolerance in solid cancer cells. Cancer Lett. 2015, 356, 828-836. [CrossRef] [PubMed]

174. Wassman, C.D.; Baronio, R.; Demir, O.; Wallentine, B.D.; Chen, C.K.; Hall, L.V.; Salehi, F.; Lin, D.W.; Chung, B.P.; Hatfield, G.W.; et al. Computational identification of a transiently open L1/S3 pocket for reactivation of mutant p53. Nat. Commun. 2013, 4, 1407. [CrossRef] [PubMed]

175. Takimoto, R.; Wang, W.G.; Dicker, D.T.; Rastinejad, F.; Lyssikatos, J.; El-Deiry, W.S. The mutant p53-conformation modifying drug, CP-31398, can induce apoptosis of human cancer cells and can stabilize wild-type p53 protein. Cancer Biol. Ther. 2002, 1, 47-55. [CrossRef] [PubMed]

176. Wang, W.G.; Takimoto, R.; Rastinejad, F.; El-Deiry, W.S. Stabilization of p53 by CP-31398 inhibits ubiquitination without altering phosphorylation at serine 15 or 20 or MDM2 binding. Mol. Cell Biol. 2003, 23, 2171-2181. [CrossRef] [PubMed]

177. Zache, N.; Lambert, J.M.R.; Rokaeus, N.; Shen, J.; Hainaut, P.; Bergman, J.; Wiman, K.G.; Bykou, V.N. Mutant p53 targeting by the low molecular weight compound STIMA-1. Mol. Oncol. 2008, 2, 70-80. [CrossRef] [PubMed]

178. Bykov, V.J.N.; Issaeva, N.; Zache, N.; Shilov, A.; Hultcrantz, M.; Bergman, J.; Selivanova, G.; Wiman, K.G. Reactivation of mutant p53 and induction of apoptosis in human tumor cells by maleimide analogs. J. Biol. Chem. 2005, 280, 30384-30391. [CrossRef] [PubMed]

179. Demma, M.; Maxwell, E.; Ramos, R.; Liang, L.; Li, C.; Hesk, D.; Rossman, R.; Mallams, A.; Doll, R.; Liu, M.; et al. SCH529074, a small molecule activator of mutant p53, which binds p53 DNA binding domain (DBD), restores growth-suppressive function to mutant p53 and interrupts HDM2-mediated ubiquitination of wild type p53. J. Biol. Chem. 2010, 285, 10198-10212. [CrossRef] [PubMed]

180. Yu, X.; Vazquez, A.; Levine, A.J.; Carpizo, D.R. Allele-specific p53 mutant reactivation. Cancer Cell 2012, 21, 614-625. [CrossRef] [PubMed]

181. Yu, X.; Blanden, A.R.; Narayanan, S.; Jayakumar, L.; Lubin, D.; Augeri, D.; Kimball, S.D.; Loh, S.N.; Carpizo, D.R. Small molecule restoration of wildtype structure and function of mutant p53 using a novel zinc-metallochaperone based mechanism. Oncotarget 2014, 5, 8879-8892. [CrossRef] [PubMed]

182. Hiraki, M.; Hwang, S.-Y.; Cao, S.; Ramadhar, T.R.; Byun, S.; Yoon, K.W.; Lee, J.H.; Chu, K.; Gurkar, A.U.; Kolev, V.; et al. Small-molecule reactivation of mutant p53 to wild-type-like p53 through the p53-HSP40 regulatory axis. Chem. Biol. 2015, 22, 1206-1216. [CrossRef] [PubMed]

183. Soares, J.; Raimundo, L.; Pereira, N.A.L.; Monteiro, A.; Gomes, S.; Bessa, C.; Pereira, C.; Queiroz, G.; Bisio, A.; Fernandes, J.; et al. Reactivation of wild-type and mutant p53 by tryptophanol-derived oxazoloisoindolinone SLMP53-1, a novel anticancer small-molecule. Oncotarget 2016, 7, 4326-4343. [PubMed] 
184. Li, D.; Marchenko, N.D.; Moll, U.M. Saha shows preferential cytotoxicity in mutant p53 cancer cells by destabilizing mutant p53 through inhibition of the HDAC6-HSP90 chaperone axis. Cell Death Differ. 2011, 18, 1904-1913. [CrossRef] [PubMed]

185. Kravchenko, J.E.; Ilyinskaya, G.V.; Komarov, P.G.; Agapova, L.S.; Kochetkov, D.V.; Strom, E.; Frolova, E.I.; Kovriga, I.; Gudkov, A.V.; Feinstein, E.; et al. Small-molecule retra suppresses mutant p53-bearing cancer cells through a p73-dependent salvage pathway. Proc. Natl. Acad. Sci. USA 2008, 105, 6302-6307. [CrossRef] [PubMed]

186. Lu, C.; Wang, W.; El-Deiry, W.S. Non-genotoxic anti-neoplastic effects of ellipticine derivative NSC176327 in p53-deficient human colon carcinoma cells involve stimulation of p73. Cancer Biol. Ther. 2008, 7, 2039-2046. [CrossRef] [PubMed]

187. Rao, B.; Lain, S.; Thompson, A.M. P53-based cyclotherapy: Exploiting the "guardian of the genome" to protect normal cells from cytotoxic therapy. Br. J. Cancer 2013, 109, 2954-2958. [CrossRef] [PubMed]

(C) 2016 by the authors; licensee MDPI, Basel, Switzerland. This article is an open access article distributed under the terms and conditions of the Creative Commons Attribution (CC-BY) license (http://creativecommons.org/licenses/by/4.0/). 